
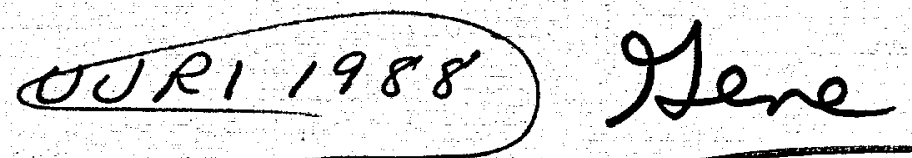

\title{
Geothermal Studies
}

at

\section{The University of Utah Research Institute}

\section{Earth Science Laboratory}

University of Utah Research Institute

391 Chipeta Way, Sulte C

Salt Lake City, Utah 84108

(801) 524-3422

July 1988

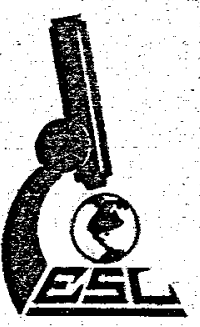




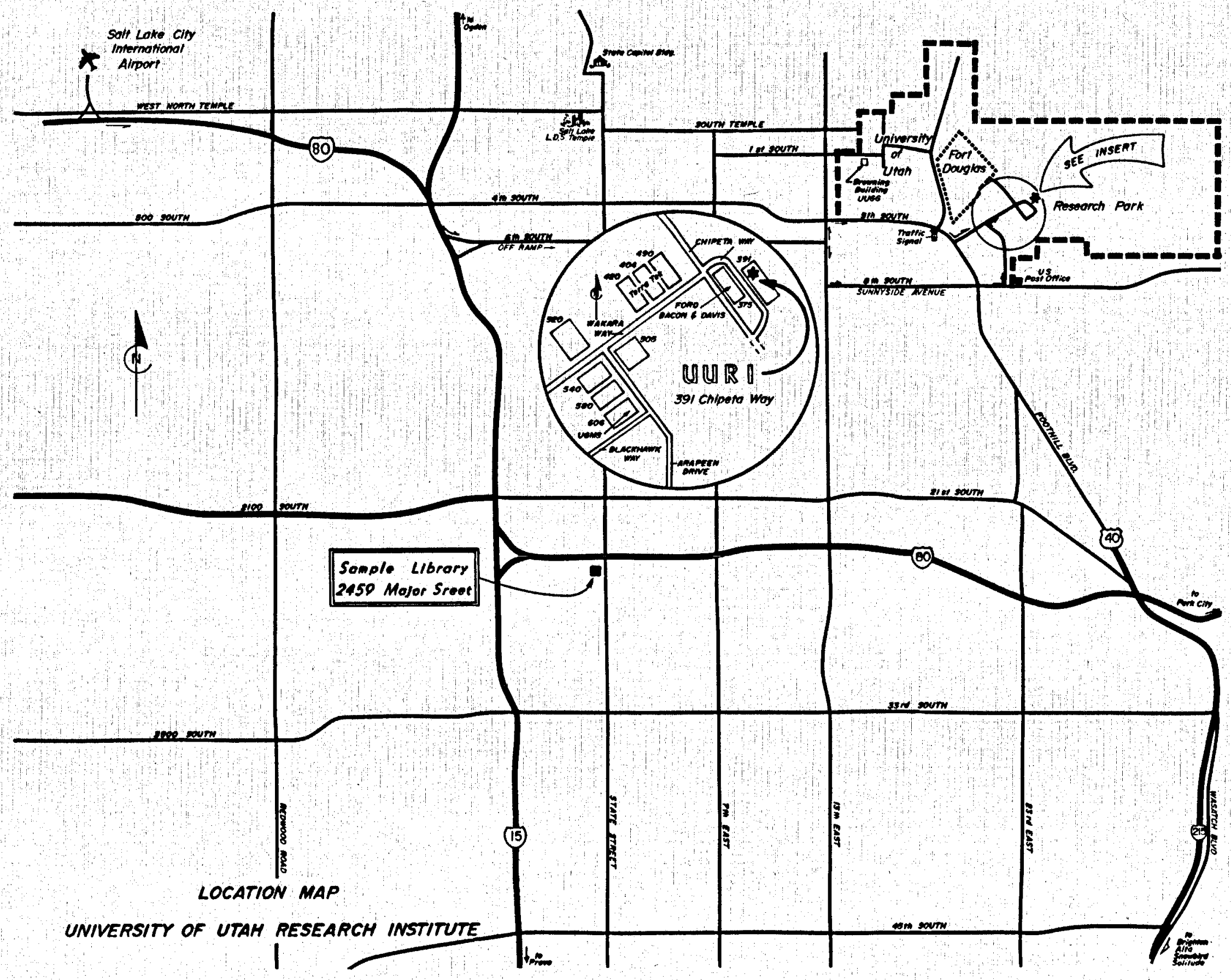




\section{DISCLAIMER}

This report was prepared as an account of work sponsored by an agency of the United States Government. Neither the United States Government nor any agency Thereof, nor any of their employees, makes any warranty, express or implied, or assumes any legal liability or responsibility for the accuracy, completeness, or usefulness of any information, apparatus, product, or process disclosed, or represents that its use would not infringe privately owned rights. Reference herein to any specific commercial product, process, or service by trade name, trademark, manufacturer, or otherwise does not necessarily constitute or imply its endorsement, recommendation, or favoring by the United States Government or any agency thereof. The views and opinions of authors expressed herein do not necessarily state or reflect those of the United States Government or any agency thereof. 


\section{DISCLAIMER}

Portions of this document may be illegible in electronic image products. Images are produced from the best available original document. 


\section{UNIVERSITY OF UTAH RESEARCH INSTITUTE}

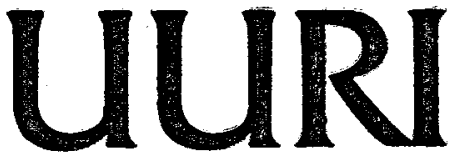

EARTH SCIENCE LABORATORY

391 CHIPETA WAY, SUITE C

SALT LAKE CITY, UTAH 84108-1295

TELEPHONE 801-524-3422

June 9, 1988

Dear Colleague:

The Earth Science Laboratory of the University of Utah Research Institute has been an integral part of the $U$. $S$. Department of Energy's geothermal research program for eleven years. This document provides a brief overview of our current geothermal research programs and accomplishments and of our staff and facilities.

Your inquiries about any of our work are welcome. We would also like to invite you to visit our facilities in the University of Utah Research Park at any time.

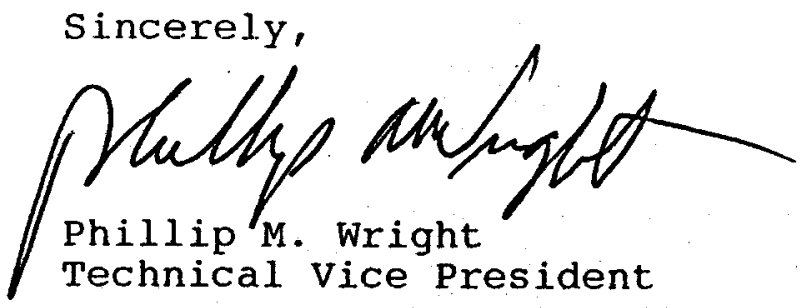

attachments

PMW : kr 
INTRODUCTION TO UURI . . . . . . . . . . . . . . . . . . .

SUMMARY OF UURI'S CURRENT GEOTHERMAL RESEARCH . . . . . . . iii

Injection Technology--Tracer Development . . . . . . ii

Fracture Characterization Research in the Baca and Coso Geothermal Systems... . . . . . . . . . . . . iv

Dipmeter Interpretation of In-situ stress and Subsurface Structure in Geothermal Wells . . . . . v Geochemical Technique Development........ . . . . vi

Development of Borehole Electrical Geophysical Techniques for Mapping Fractures in Geothermal Systems . . . . . . . . . . . . . . . .

Development of the Magnetotelluric Method

Evaluation of the Use of Time-Dependent Self-potential to Determine Geothermal Reservoir Characteristics

Feasibility study for the Measurement of Conductivity and Specific Ion Concentrations Downhole Using Solid Electrodes... . . . . . . . . . . .

Cascades Technical Assistance . . . . . . . . . . . . xi Characterization of Cascades Reservoirs . . . . . . . . xii Mexico Cooperative Research . . . . . . . . . xii xi

GEOTHERMAL RESEARCH STAFF AND ASSIGNMENTS . . . . . . . . . . XV

FACILITIES . . . . . . . . . . . . . . . . . . xix

Geochemical Laboratory . . . . . . . . . . . . . .xix X-Ray Diffraction Laboratory . . . . . . . . . . . xix Physical Properties Laboratory . . . . . . . . . . . . xix Geophysical Electronics Laboratory . . . . . . . . . . xx Remote Sensing Laboratory . . . . . . . . . . . $x \mathbf{x}$ Computer . . . . . . . . . . . . . . . . xxi Geothermal Sample Library . . . . . . . . . . xxii

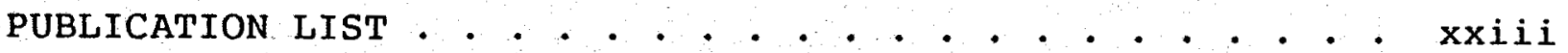

Explanation . . . . . . . . . . . . . . xxiii

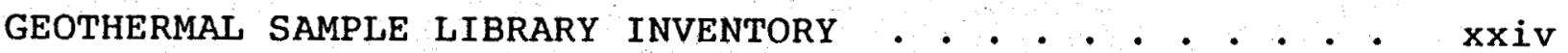


Figure 1

Figure 2

Figure 3

Figure 4
Location Map -

Inside Front Cover

University of Utah Research Institute Organization

Location Map - Drill Hole Samples in Geothermal

Sample Library

xxiv

UURI's Worldwide Geothermal

Experience

Inside Back Cover

\section{TABLES}

Table 1

Table 2

Research Staff Assignments

Earth Science Laboratory Research Staff

Page

$\mathrm{xv}$

xvi 


\section{INTRODUCTION TO UURI}

The University of Utah Research Institute (UURI) is a selfsupporting corporation organized in December 1972 under the Utah Non-Profit Corporation Association Act. Under its charter, the Institute is separate in its operations and receives no direct financial support from either the University of Utah or the State of Utah. The charter includes provisions for UURI to conduct both public and proprietary scientific work for governmental agencies, academic institutions, private industry, and individuals.

UURI is composed of five divisions, shown in Figure 1: the Earth Science Laboratory (ESL), the Environmental Studies Laboratory (EVSL), the Center for Remote Sensing and Cartography (CRSC), the Engineering Technology Laboratory (ETL) and the Atmospheric Physics Laboratory (APL). The Earth Science Laboratory has a staff of geologists, geochemists and geophysicists who have a broad range of experience in geothermal research and field projects (see inside back cover) as well as in mineral and petroleum exploration. The Environmental studies Laboratory offers a variety of technical services and research capabilities in the areas of air quality and visibility, acid precipitation, surface and groundwater contamination, and environmentally caused stress in vegetation. The Center for Remote sensing and Cartography offers applied research and services with a full range of remote sensing and mapping 
capability, including satellite and airborne imagery processing and interpretation. The Engineering Technology Laboratory is currently studying the interaction of the human body with electromagnetic radiation. The Atmospheric Physics Laboratory is developing hygroscopic droplet growth theory and orographic seeding models for dispersal of fog.

\section{The University of Utah Research Institute ORGANIZATION}

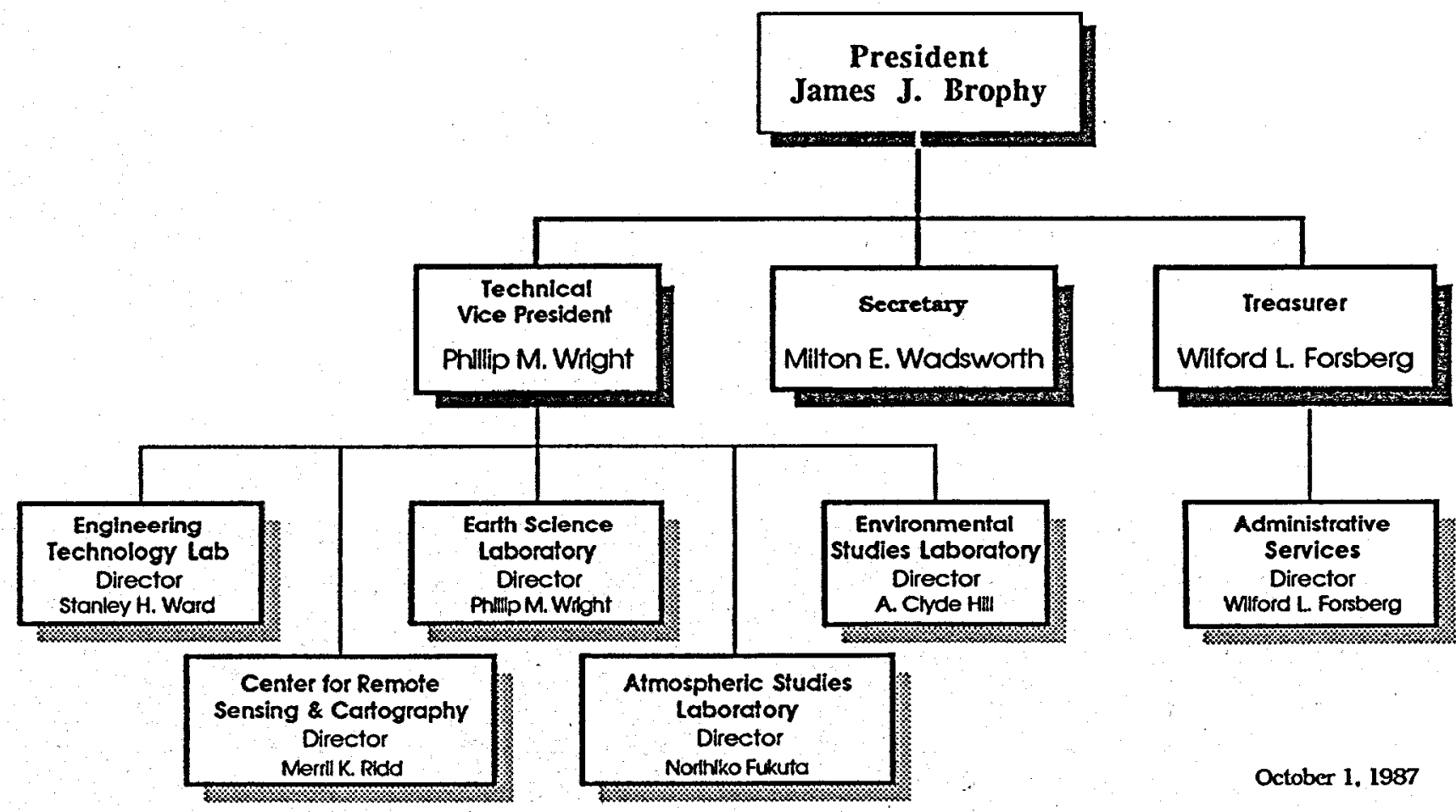




\section{SUMMARY OF UURI'S CURRENT GEOTHERMAL RESEARCH}

For the past eleven years, the Earth Science Laboratory of

UURI has been involved in geothermal energy research on behalf of the U. S. Department of Energy. Our work has predominately concerned the development of new exploration, reservoir definition and mapping techniques for hydrothermal systems. We maintain a commitment to be of assistance in our work to the geothermal industry. Comments and suggestions regarding our research work are always welcome.

This section gives a brief overview of our current research efforts. Our past work is documented in the last section of this document, which gives a list of our geothermal publications.

\section{INJECTION, TECHNOLOGY--TRACER DEVELOPMENT} Background

Breakthrough of injected fluids into production wells may significantly decrease the useful life of a geothermal field. Such breakthrough has now been observed, or is suspected, in a number of structurally controlled geothermal systems. Tracers provide the most direct means of monitoring the movement of the injected fluids. The development of new tracers, better suited to the geothermal environment than the few that are currently available, has been the major objective of UURI's tracer research program. As a result of this program, 23 derivitized hydrocarbons have been identified that appear to be stable up to 
temperatures of $200^{\circ} \mathrm{C}$. Of these, 15 have been shown to be stable at $250^{\circ} \mathrm{C}$. The long-term in-situ stabilities of these compounds and the effects of rock-tracer interactions however, have not yet been established.

\section{Objectives}

Our primary research objective is to develop and test chemical tracers for the geothermal industry to use. The objectives of the current research are 1) to establish the decay rates and determine the effects, if any, of geothermal reservoir rocks on the compounds that appear to be most appropriate for use in high-temperature, liquid-dominated systems; 2) to establish the fleld procedures required for the handling, injection, and sampling of the tracers; and, 3) to perform one or more field tests of the candidate tracers in actual hydrothermal wells.

FRACTURE CHARACTERIZATION RESEARCH IN THE BACA AND COSO GEOTHERMAL SYSTEMS

\section{Background}

Ongoing fracture research has been focused on two dissimilar, active high-temperature liquid-dominated geothermal systems: the Baca system in the Valles caldera in New Mexico, and the coso system in southern California. Whereas coso rocks are obscured by a complex array of hydrothermal overprints, the very young rocks at Baca are characterized by simple, readily deciphered alteration signatures. Continuous core from recently completed, strategically situated, intermediate-depth (1700-2800 
ft) coreholes at both Baca and Coso has greatly assisted in detailed fracture and alteration research. At Baca, we have recognized the importance of natural hydrofracturing to reservoir development and have improved the conceptual geologic model of the system to include the depth of hydrothermal brecciation, the contemporaneous state of stress, and the energy required to hydrofracture. At Coso, clay mineral geothermometry and fluidinclusion microthermometry, when compared with current temperature profiles in the boreholes, suggest that the field has heated somewhat since the clays and associated hydrothermal phases were deposited.

objectives

The objectives of this research are to describe and quantify the structural style and the development and evolution of geothermal reservoirs for the purpose of generating better conceptual geological and geochemical models for use by Industry in exploration and reservoir engineering.

DIPMETER INTERPRETATION OF IN-SITU STRESS AND SUBSURFACE STRUCTURE IN GEOTHERMAL WELLS

\section{Background}

Recent advances in dipmeter technology, processing and interpretation make it one of the most powerful well logging tools avaliable for determining subsurface structure and stress. Most dipmeter logs have been run in petroleum exploration wells in sedimentary environments and few of these data have been 
publicly released. The use of dipmeter logs in igneous or volcanic rocks is virtually unheard of, but has great potential for assisting in structural studies.

Objectives

The major goal is to demonstrate the effectiveness and usefulness of dipmeter logs in geothermal wells in igneous and volcanic sequences. Positive results will 1) lead to the availability of a new tool for structural studies of geothermal systems, and 2) encourage the logging industry to develop higher temperature tools.

GEOCHEMICAL TECHNIQUE DEVELOPMENT

Background

Permeability and temperature distribution within a geothermal reservolr affect the isotopic and chemical composition of the geothermal fluid and produce characteristic mineral assemblages. Often, the permeability and temperature distributions either cannot be measured or have changed with time due to fracture sealing. The signature of the distribution, however, is left in the minerals and thelr fluid inclusions. For instance, heating and freezing measurements of fluld inclusions can reveal the past or present temperatures and fluid salinities in the reservoir. Isotopic analysis of the minerals, combined with the fluid inclusion temperature data, can indicate the degree of oxygen-isotope shift in the fluid, which is a function 
of permeability. The composition of the fluid in the fluid inclusion indicates permeability distributions as related to boiling and mixing of the fluids. From these data, permeability variations in the reservoir through time and space can be measured.

\section{objectives}

The objective of this research is to describe and quantify the evolution of geothermal reservoirs as evidenced from chemical, thermal, and isotopic changes in the fluids and minerals. This will lead to better models of the chemistry and fluid flow paths in hydrothermal systems.

DEVELOPMENT OF BOREHOLE ELECTRICAL GEOPHYSICAL TECHNIQUES FOR MAPPING FRACTURES IN GEOTHERMAL SYSTEMS

\section{Background}

For the last several years, we have been developing computer-based methods to evaluate the use of borehole geophysical techniques for locating fractures and permeable zones in geothermal systems. Our work has progressed to the point where we are ready to build a field system. We have begun to pursue methods for interpretation of field results. Objectives

The objective of this research is to develop borehole electrical survey methods capable of detecting fractures and permeable zones in the walls of exploration holes in geothermal fields. This will enable the geothermal operator to increase the 
odds of success in drilling and, therefore, to save money in geothermal development.

This research has both interpretation and instrumentdevelopment tasks. We will continue to develop new computer algorithms to interpret the response of electrical geophysical techniques to fractures and permeable zones in geothermal wells. Present research will be directed toward: 1) the development of inverse algorithms for the modeling of surface-to-borehole, borehole-to-surface and borehole-to-borehole data; 2) testing of the algorithms on field data sets; and 3) reporting the results. We will also build a multi-array borehole electrical geophysical system capable of performing borehole-to-surface, borehole-toborehole, and surface-to-borehole resistivity and induced polarization measurements.

DEVELOPMENT OF THE MAGNETOTELLURIC METHOD Background

Although the magnetotelluric geophysical method has been used in the geothermal exploration by industry, its use has not been juaged to be very cost effective. We believe that the primary reasons for this lack of success is that available instruments have not been capable of obtaining the very highquality data that are needed for proper interpretation in complex environments and that interpretation techniques have not been adequate. Interpretation of the majority of MT data has been 
done using layered-earth, one-dimensional methods that are unsuitable for use in the geothermal environment, where the resistivity structure is variable in three dimensions, both with depth and lateraliy.

Objectives

Our objective is to develop improved instrumentation and interpretation techniques and to demonstrate how the MT technique can be used cost-effectively in geothermal exploration.

EVALUATION OF THE USE OF TIME-DEPENDENT SELF-POTENTIAL TO DETERMINE GEOTHERMAL RESERVOIR CHARACTERISTICS

\section{Background}

The self-potential method relies on the measurement of electrical potentials created by changes in fluid pressure, temperature or solute concentration. We have previously used the conventional SP method to monitor the effects of injection at Raft River and East Mesa with limited success. We propose to evaluate a refinement in the self-potential method, which we term the "time dependent self-potential (TDSP) method". To implement the method, an array of semi-permanent, non-polarizing electrodes is placed around $a$ well and a base level of potential

established. Next, production or injection is begun and the potential, relative to the base level, is measured for each electrode in the array during a short time interval, with the measurements being repeated for a series of times throughout the test. In this way, it may be possible to follow the pressure or 
chemical fronts induced by flowing or injecting into the well. By numerical modeling of the data, it is hoped that a two- or three-dimensional picture of the general permeability structure In the vicinity of the well can be developed.

\section{Objectives}

Our objective is to develop the TDSP method as a new geophysical tool for determining the permeability structure around a geothermal well and tracing the flow of fluid in the vicinity of a well.

FEASIBILITY STUDY FOR THE MEASUREMENT OF CONDUCTIVITY AND SPECIFIC-ION CONCENTRATIONS DOWNHOLE USING SOLID ELECTRODES

\section{Background}

If a borehole logging tool could be developed to measure conductivity, $\mathrm{pH}$, and concentrations of specific ions such as chlorine, magnesium, and sodium in situ, it would be a very useful. tool in exploration and characterlzation of geothermal resources. It may be possible to develop such a tool using solid electrode technology for the sensing elements.

Different electrode materials are sensitive to the presence of particular ions in solution and produce different response curves of voltage vs current as the concentration of ions to which individual electrodes are sensitive varies. The response curves will vary as a function of temperature and there will almost certainly be interactions, $i . e .$, one electrode may respond to multiple ions in solution or multiple electrodes may respond 
in different ways to an individual ion in solution. It may be possible, however, through appropriate choices of electrodes and measurement procedures, to obtain sufficient electrode response data to allow application of nonlinear optimization algorlthms to invert the data set for individual ion concentrations. Objectives

The current objective of this research is to determine the feasibility of using solid specific-ion electrodes to perform chemical analyses on geothermal fluids down-hole.

\section{CASCADES TECHNICAL ASSISTANCE}

\section{Background}

During the past three fiscal years, DOE has participated in a cost-sharing arrangement with three geothermal developers to core $4,000 \mathrm{ft}$ to $5,000 \mathrm{ft}$ holes in the Cascades for research purposes. One of the over-riding questions in exploration in the Cascades region has been the nature and thickness of the zone of cold-water overflow. GEO-Newberry has completed two holes on the flanks of Newberry volcano, Thermal Power Corp. has cored one hole on the north flank of Mt. Jefferson and California Energy has begun a core hole on the southeast flank of Mt. Mazama volcano, in which Crater Lake is located. The California Energy hole was suspended nearly two years ago and coring has not been resumed to date. 


\section{Objective}

The objective of this project is to provide DOE with technical assistance in this program and to collect and release all of the data generated to the public.

\section{CHARACTERIZATION OF CASCADES RESERVOIRS}

\section{Background}

Rocks of the Western Cascades province are known to be regionally altered and metamorphosed to the zeolite facies. The result of this regional alteration is that the primary porosity and permeability of these rocks have been largely destroyed. Because Western Cascades rocks are believed to underlie the High Cascades, a significant question revolves around the nature of permeability at depth in the High Cascades, where intrusive processes are active to provide heat for geothermal systems.

During FY 87, we initiated studies of the mechanical properties of Cascades rocks. We also initiated a study of the Glacier Peak disseminated mineral system, which was formed by hydrothermal processes. Using information from these studies, we have learned a great deal about the structural style that geothermal reservoirs may be expected to take in the Cascades. These studies need further work for completion.

Electrical geophysical surveys have been performed by others in the vicinities of the Clackamas and Newberry coreholes, and the coreholes intersected the sources of resistivity lows that 
the surface surveys found. The geologic explanation for the resistivity lows appears to be low-temperature lllite-smectite: alteration of volcanic rocks. There is no obvious way at present to separate such resistivity lows due to low-temperature alteration from resistivity lows due to high-temperature geothermal systems.

Objectives

The objectives of this project are to identify the rock types and/or structural conditions in the Cascades that are most likely to facilitate the formation of geothermal reservoirs, and to determine the exploration significance of the results.

other objectives concern the measurement of physical properties of core from the Cascades and other similar volcanic environments for the purpose of determining whether or not some geophysical method might be capable of distinguishing between resistivity lows detected on surface geophysical surveys that are due to low-temperature alteration and resistivity lows that are due to high-temperature alteration.

\section{MEXICO COOPERATIVE RESEARCH}

\section{Background}

The Mexican Government, through the Comision Federal de Electricidad (CFE), has undertaken a major geothermal development program at the Los Azufres geothermal field in central Mexico, during which they have collected a great deal of data. These 
data, as well as drill chip samples and fluid samples from production tests, could be very useful in terms of the research underway at UURI because the setting of Los Azufres in many ways parallels the setting of volcanic-related geothermal systems in the United States.

During FY 87, we Initiated cooperative research work with the Mexicans at Los Azufres and Cerro Prieto. Our cooperative work so far includes 1) study of drill chips from selected wells and exploration holes in the system at Los Azufres, 2) study and interpretation of geochemical data from the fluids, 3) joint studies of the application of chemical tracers to the system, 4) performing of an aeromagnetic survey over Los Azufres, and 5) work with Mexican geophysiclsts to help interpret resistivity data over the system by incorporation of the effects of topography on data which they had previously obtained. Objective

The objectives of this project are to: 1) work with our Mexican colleagues to form a better understanding of the Los Azufres and Cerro Prieto geothermal systems, to the mutual benefit of both sides; and 2) obtain, interpret and publish pertinent data on these Mexican geothermal systems for the benefit of the U.S. geothermal industry. 
GEOTHERMAL RESEARCH STAFF AND ASSIGNMENTS

The Earth Science Laboratory of UURI maintains a full-time, permanent geothermal research staff which is supplemented by Research Associates, University of Utah faculty and students. Table 1 shows the distribution of this staff. Not all of our Research Associates are currently working on geothermal research projects.

TABLE 1

EARTH SCIENCE LABORATORY RESEARCH STAFF

Permanent staff

Geology

Ph.D.

B.S.

Geochemistry

$\mathrm{Ph} . \mathrm{D}$.

M.S.

B.S.

Geophysics

Ph.D.

2

1

1

1

2

4

Remote Sensing

Remote Sensing 1

Electronics

B.S.

1

13

Total
Research Associates

Geology

Ph.D.

2

Geochemistry

Ph.D.

2

Geophysics

Ph.D.

B.S.

Students

1

Remote Sensing

students

1

Environmental Sciences

M.S.

1

Geohydrology

Ph.D.

2

Total 
The distribution of research staff assignments is shown

below in Table 2. An asterisk denotes the primary research scientist to contact for more information on a particular topic.

TABLE 2

RESEARCH STAFF ASSIGNMENTS

\title{
GEOLOGY
}
M. Lee Allison - *Borehole breakout studies Senior Geologist - *Dipmeter interpretation
- Structural studies, geothermal systems
- Ascension Project
Jeff Hulen
- *Manager, X-ray Diffraction Laboratory Senior Geologist
- *racture permeability and alteration studies at Coso Hot Springs and Valles caldera
- Geologic models of hydrothermal systems
Dennis Nielson Senior Geologist Section Head/ Geology
- Fracture permeability and alteration in geothermal systems,
- *Geologic models of hydrothermal systems
- *Cascades geological models
- *Manager, Ascension Project

\author{
GEOCHEMISTRY \\ Mike Adams \\ Geochemist \\ - *Chemical tracer development \\ - *Tracer tests in geothermal systems \\ - Geochemistry of geothermal systems \\ Judy Ballantyne
Research Associate \\ - Alteration and geochemistry of geothermal \\ systems \\ - *Clay formation in geothermal systems \\ Ruth Kroneman \\ Senior Analytical \\ Chemist \\ - *Manager, UURI Analytical Chemistry \\ Laboratory \\ - *Analytical technique development \\ Michele Lemieux \\ Geological \\ Engineer \\ - Fluid inclusion studies \\ - Physical property studies \\ - * Cascades research coring program
}


TABLE 2 cont.

REMOTE SENSING

Doug Ramsey

- *Project Manager/Digital Image processing

Graduate student - Remote sensing study, Los Azufres

xviii 


\section{FACILITIES}

UURI has about $15,000 \mathrm{sq}$. ft. of laboratory and office space In Research Park, adjacent to the University of Utah campus (see Location Map, inside front cover). We also have about $6,000 \mathrm{sq}$. ft. of storage space for core and chip samples from geothermal areas.

\section{Geochemical Laboratory}

A geochemical laboratory designed especially for geothermal and mineral studies has been operational since 1977. The laboratory is equipped with an ARL Inductively Coupled Plasma Spectrometer (ICP), capable of analyzing 37 elements simultaneously, an IL Atomic Absorption Spectrophotometer, a Jerome Gold Film Mercury Detector, an Orion Specific Ion Meter and electrodes, and complete sample preparation facilities. In addition, an electron microprobe, a scanning electron microscope, and $\mathrm{K}-\mathrm{Ar}$ and fission track age dating are also available.

\section{X-Ray Diffraction Laboratory}

Our x-ray diffraction laboratory is equipped with a Philips Model $3100 \mathrm{x}$-ray unit for the identification of primary and secondary minerals in rocks from geothermal systems.

\section{Physical Properties Laboratory}

UURI maintains laboratory facilities for the in-house determination of a variety of physical property measurements and 
associated chemical properties. Measurement capabilities include: electrical resistivity/induced polarization; cation exchange capacity; magnetic susceptibility; remanent magnetism; thermal conductivity, density and porosity.

\section{Geophysical Electronics Laboratory}

The Electronics Laboratory is well equipped for development of microprocessor-integrated geophysical instrumentation. Test, design, and prototype construction facilities are state-of-theart. Recent projects include: 1) the redesign and modification of a state-of-the-art magnetotelluric recording system; 2) system integration of a portable (button-on) aeromagnetic data acquisition system which incorporates a radar altimeter and VHS recording of flight path and digital magnetic and altimeter data; and 3) instrumentation for remote monitoring of landsiides.

\section{Remote Sensing Laboratory}

UURI has available a variety of software and hardware for use in remote sensing application and research. A large portion of our software is integrated into the image processing package called ELAS (Earth Resources Laboratory Application Software) designed and written by NASA's National Space Technology Laboratories, Earth Resources Laboratory. ELAS is currentIy one of the most powerful tools for the analysis of remotely sensed data. Its capabilities include the analysis of any digitally based remote sensing data collected from spaceborne, airborne or 
ground based sensors. UURI is a NASA distribution center for this software.

CRSC currently operated ELAS from an in-house PRIME 2655 super minicomputer. Digitizing capabilities include a Tektronic 4954 digitizing tablet interfaced with a Tektronic 4014-1 graphics monitor. RGB color monitor capabilities include an Advanced ELectronic Design (AED) 767 high-resolution display device.

Backup and support to ELAS is provided by the micro-based ERDAS image processing system and geographic information system (GIS). ERDAS currently runs on an enhanced IBM PC/AT with 40 megabyte capability.

\section{Computer}

Computer facilities consist of a PRIME 2655 super minicomputer system with links to the University of Utah's UNIVAC Computer Center and to the San Diego Supercomputer Center. The system includes a PRIME 2655 CPU with time-sharing capability and virtual memory, $4 \mathrm{M}$ bytes of main memory, $615 \mathrm{M}$ bytes of disk storage, a 9-track magnetic type drive, a 36-inch zeta pen plotter, two line printers, 2 Tektronix 4014 graphics terminals with digitizing tablets, a DECwriter terminal and $15 \mathrm{CRT}$ terminals. Three dial-in phone lines are available to users. The system is specifically oriented to scientific and engineering computation and to handling and interpreting geoscience data. 
Geothermal Sample Library

The Geothermal Sample Library provides open-file accessibility and archival storage for both public domain and proprietary field and drill samples: At present, the Library contains over 80,000 meters of drill samples and 25,000 meters of core from more than 180 shallow thermal gradient holes and deep holes, mainly from geothermal areas of the western United states. Included are samples from 14 Industry Coupled Program areas in Utah and Nevada; Coso KGRA, California; Raft River, Idaho; and Cascades Range, Oregon; and sample from DOE and private geothermal projects in Wyoming, Colorado, Idaho, Washington, Oregon, California, and New Mexico.

The sample library has been used to archive samples from DOE projects and to distribute samples for authorized research and study. It has been used to advantage by geologists and researchers in preparation for new drilling within the represented areas, and for comparison with drill samples from their own project areas. Chipboards have been prepared for most DOE-supported geothermal holes in order to facilitate study. Downhole geophysical and temperature logs from many geothermal wells are also archived at UURI.

A current inventory of drill core and cuttings curated at the Library and a map summarizing the more important sample collection in the western United States is Included in the Geothermal Sample Library Inventory, later in this document. 


\section{UNIVERSITY OF UTAH RESEARCH INSTITUTE}

EARTH SCIENCE LABORATORY

PUBLICATION LIST

JUNE 1988

\section{Explanation}

This publication 11st includes technical reports, progress reports, journal publications, and meeting abstracts completed by ESL/UURI under Department of Energy funding since 1978. Geothermal reports and publications completed by the Department of Geology and Geophysics, University of Utah, are also listed. Final or selected other projects completed by ESL/UURI for other government (1. e., U. S. Geologlcal Survey, U. S. Bureau of Mines) or United Nations agencies are also included.

ESL/UURI reports may be obtained from UURI at reproduction and handiling costs. Reprints of journal publications are sometimes avallable upon request to the author.

Publications, $1978 \ldots \ldots \ldots \ldots$

Publications, $1979 \ldots \ldots \ldots \ldots$

Publications, $1980 \ldots \ldots \ldots \ldots$

Publications, 1981 . . . . . . . . . . . . 6

Publications, $1982 \ldots \ldots \ldots \ldots$

Publications, 1983 . . . . . . . . . . . . . . 14

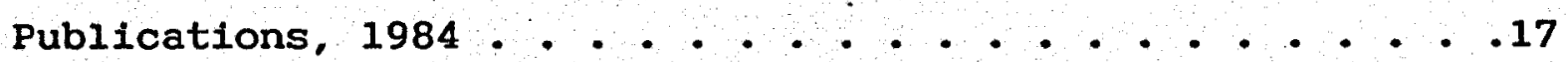

Publications, 1985 . . . . . . . . . . . . . 18

Publications, 1986 . . . . . . . . . . . . . . 23

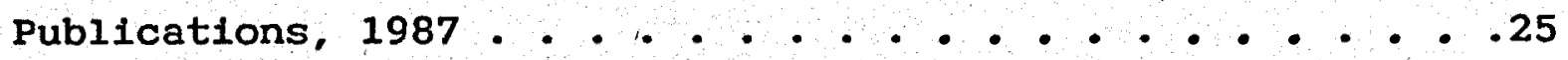

Publications, $1988 \ldots \ldots \ldots \ldots$ 
Bamford, R. W., 1978, Geochemistry of solid materials from two U.S. geothermal systems and its application to exploration: DOE/ID/77-14, ES.L Rept. No. 6.

Capuano, R. M., and Bamford, R. W., 1978, Initial investigation of soll mercury geochemistry as an aid to drill site selection in geothermal systems: DOE/ID/28392-20, ESL Rept. No. 13.

Fox, R. C., 1978, Dipole-dipole resistivity of a portion of the Coso Hot Springs KGRA, Inyo County, California: DOE/ID/77-5.6, ESL Rept. NO. 2.

Fox, R. C., 1978, Low-altitude aeromagnetic survey of a portion of the Coso Hot Springs KGRA, Inyo County, California: DOE/ID/77-5.7, ESL Rept. NO. 4.

Galbraith, R. M., 1978, Geological and geophysical analysis of Coso geothermal Exploration Hole No. 1 (CGEH-1), Coso Hot Springs KGRA, California: DOE/ID/28392-5, ESL Rept. No. 5.

Hohmann, G. W., and Ting, S. C., 1978, Three-dimensional magnetoteliuric modeling: DOE/ID/28392-13, ESL Rept. No. 7.

Hulen, J. B., 1978, Geology and alteration of the Coso Geothermal Area, Inyo Co., California: DOE/ID/28392-4, ESL Rept. No. 3.

Hulen, J. B.. 1978, Stratigraphy and alteration of fifteen shallow thermal gradient holes, Roosevelt H.S. KGRA and vicinity, Millard and Beaver Counties, Utah: DOE/ID/28392-9, ESL Rept. NO. 9.

McKinney, D. B., 1978, Annotated bibliography of the geology of the Roosevelt Hot Springs Known Geothermal Resource Area and the adjacent Mineral Mountains: DOE/ID/28392-10, ESL Rept. No. 10.

Nielson, D. L., 1978, Radon in geothermal exploration: Theory and an example from Roosevelt Hot Springs KGRA, Utah: DOE/ID/28392-18, ESL Rept. No. 14, 31 p.

Nielson, D. L., Sibbett, B. S., McKinney, D. B., Hulen, J. B., Moore, J. N., and Samberg, S. M., 1978, Geology of Roosevelt Hot Springs KGRA, Beaver County, Utah: DOE/ID/28392-19, ESL Rept. No. 12,121 p. 


\section{8 cont.}

Ross, H. P., 1978, Numerlcal modeling of apparent resistivity profiles, Dipole-dipole Iines 6, 7, 8; Olkaria Geothermal Field, Kenya: presented to United Nations, ESL Rept. No. 1.

Ross, H. P., and Lundbeck, J., 1978, Interpretation of resistivity and induced polarization profiles, Calico Hilis and Yucca Mountain Areas, Nevada Test Site: Presented to U.S. Geological Survey, ESL Rept. No. 8.

Ross, H. P., Smith, C., and Atwood, J. W., 1978, Numerical modeling and interpretation of dipole-dipole resistivity data, Lakes District, Ethiopia: Presented to United Nations, ESI Rept. No. 17.

\section{9}

Bamford; R. W., and Christensen, O. D., 1979, Multielement geochemical exploration data for the Cove Fort/Sulphurdale KGRA, Beaver and Millard counties, Utah: DOE/ID/28392-28, ESL Rept. No. 19.

Fox, R. C., Ross, H. P., and Wright, P. M., 1979, Dipole-dipole resistivity survey of a portion of the Coso Hot springs, KGRA, InYo County, California: Geophysics, ESL-79002-ABS.

Glenn, W. E., and Hulen, J. B., 1979, Interpretation of well log data from four drill holes at Roosevelt Hot Springs KGRA: DOE/ID/2839238, ESL Rept. No. 28 .

Hohmann, G. W., and Jiracek, G. R., 1979, Dipole-dipole interpretation with 3D models (including a field study of Las Altruas, New Mexico): DOE/ID/28392-29, ESL Rept. No. 20 .

Hulen, J. B., 1979, Geology and alteration of the Baltazor H.S. and Painted Hills Thermal Areas, Humboldt County, Nevada: DOE/ID/2839236, ESL Rept. No. 27.

Killpack, T. J., and Hohmann, G. W., 1979, Interactive dipole-dipole resistivity and IP modeling of arbitrary two-dimensional structures (IP2D Users Guide and Documentation): DOE/ID/28392-22, ESL Rept. No. 15.

Moore, J. N., 1979, Geology map of the San Emidio Geothermal Area, NV: DOE/ID/28392-33, ESL Rept. No. 23. 


\section{9 cont.}

Moore, J. N., and Samberg, S. M., 1979, Geology of the Cove FortSulphurdale KGRA with bibliographic annotations and petrographic descriptions by B. S. sibbett: DOE/ID/28392-27, ESL Rept. No. 18.

Nielson, D. L. (ed., ), 1979, Program Review, Geothermal Exploration and Assessment Technology Program (Including a Report of the Reservolr Engineering Group): DOE/ID/27002-6, ESL Rept. No. 29, 128 p.

Ross, H. P., 1979, Numerical modeling and interpretation of dipole-dipole resistivity and IP profiles, Cove Fort-Sulphurdale KGRA, UT: DOE/ID/28392-37, ESL Rept. No. 26 .

Ross, H. P., and Smith, C., 1979, Interpretation of resistivity and induced polarization profiles with severe topographic effects, Yucca Mountain Area, Nevada Test Site: Presented to U.S. geological Survey, ESL Rept. No. 21.

Ross, H. P., Smith, C., Glenn, W. E., Atwood, J. W., and Whipple, R. W., 1979, Numerical modeling and interpretation of dipole-dipole resistivity data, Olkaria Field, Kenya: Presented to United Nations, ESL Rept. No. 16.

sibbett, B. S., 1979, Geology of Soda Lake Geothermal Area, NV: DOE/ID/28392-34, ESL Rept. No. 24.

Ward, S. H., Ross, H. P., and Nielson, D. L., 1979, A strategy of exploration for high-temperature hydrothermal systems in the Basin and Range provinces: DOE/ID/27002-5, ESL Rept. No. 22 .

\section{0}

Atwood, J. W., Glenn, W. E., and Killpack, T. J.., 1980, Computer system for digitizing, analyzing, and plotting well log data (A User's Guide to WELLOG REV.1): DOE/ID/12079-1, ESL Rept. No. 31 .

Bamford, R. W., Christensen, O. D., and Capuano, R. M., 1980, Multi-element geochemistry of solid materials in geothermal systems and its application - Part 1: The hot-water system at the Roosevelt Hot Springs KGRA, Utah: DOE/ID/27002-7, ESI Rept. No. 30 .

Bruhn, R. L., Yusas, M. R., and Huertas, F., 1980, Mechanics of lowangle faulting, Roosevelt Hot Springs: Tectonophysics, DOE/ID/1207935. 


\section{0 cont.}

Christensen, O. D., 1980, Geochemistry of the Colado Geothermal Area, Pershing County, NV: DOE/ID/12079, ESL Rept. No. 39.

Christensen, O. D., 1980, Trace element geochemistry of gradient hole cuttings, Beowawe Geothermal Area, Nevada:

DOE/ID/12079-21, ESL Rept. No. 48.

Christensen, O. D., Kroneman, R. L., and Capuano, R. M., 1980, Multi-element analysis of geologic materials by inductively coupled plasma-atomic emission spectroscopy:

DOE/ID/12079-2, ESL Rept. No. 32 .

Cole, D. R., and Ohmoto, H., 1980, Mechanisms and rates of oxygen-isotope exchange in experimental hydrothermal systems: DOE/ID/1207954.

Crecraft, H., Nash, W. P., and Evans, S. H., 1980, Petrology, geochronology, and chemlcal evolution of the Twin Peaks rhyolite domes, Utah: DOE/ID/12079-4.

Evans, S. H., and Brown, F. H., 1980, Summary of potassium/argon age dating: $\mathrm{DOE} / \mathrm{ID} / 12079-23$.

Fox, R. C., Hohmann, G. W., Killpack, T. J., and Rijo, L., 1980, Topographic effects in resistivity surveys: DOE/ID/28392-11, ESL Rept. No. 11, Geophysics, 46, 182-197.

Frangos, W., and Ward, S. H., 1980, Dipole-dipole survey at Roosevelt Hot Springs KGRA, Beaver County, Utah:

DOE/ID/12079-15, ESL Rept. No. 43.

Glenn, W. E.. Chapman, D. S., Foley, D., Capuano, R. M., sibbett, B. S., Cole, D. R., and Ward, S. H., 1980, Geothermal program, Hill AFB, Davis and Weber Counties, Utah: DOE/ID/28392-42, ESL Rept. No. 34, 77 p.

Glenn, W. E., Ross, H. P., and Atwood, J., 1980, Review of well logging in the Basin and Range Known Geothermal Resource Areas: Paper SPE 9496, SPE/AIME, ESL-80002JP.

Green, R. T,, and Cook, K. L., 1980, A gravity survey of the southwestern part of the southern Utah geothermal belt, Washington County, Utah: DOE/ID/12079-18, ESL Rept. No. 46.

Lynch, W. C., and Nash, W. P., 1980, Chemical trends in Ice Springs basalt, Black Rock Desert, Utah: DOE/ID/12079-12. 
1980 cont.

Mackelprang, C. E., 1980, Interpretation of a dipole-dipole electrical resistivity survey, Colado Geothermal Area, Pershing County, Nevada: DOE/ID/12079-11, ESL Rept. No. 41.

Mackelprang, C. E., Moore, J. N., and Ross, H. P., 1980, A summary of the geology and geophysics of the San Emidio KGRA, Washoe County, Nevada: ESL-80001-JP.

Maurer, J., and Atwood, J. W., 1980, GM3D: Interactive 3D gravity and magnetic modeling program (GM3D REV.1 User's Guide): DOE/ID/1207916, ESL Rept. No. 44.

Nutter, C., 1980, GRAV2D, An interpretative 2-1/2 dimensional gravity modeling program (User's Guide and Documentation for REV.1): DOE/ID/ 12079-13, ESL Rept. No. 42.

Nutter, C., and Wannamaker, P. E., 1980, MT3D: A three-dimensional magnetoteliuric modeling program (User's Guide and Documentation for REV.1): DOE/ID/12079-20, ESL Rept. No. 47.

Nutter, C., Atwood, J. W., Killpack, T. J., and Glenn, W. E., 1980, WELLOG: Computer software system for analyzing and plotting well log data (A User's Gulde to WELLOG REV.2): DOE/ID/12079-17, ESL Rept. No. 45.

Pe, W., and Cook, K. L., 1980, Gravity survey of the Escalante Desert and Vicinity, in Iron and Washington Counties, Utah: DOE/ID/1207914.

Sandberg, S. M., and Hohmann, G. W., 1980, Controlled-source audiomagnetotellurics in geothermal exploration: DOE/ID/12079-5.

Sibbett, B. S., 1980, Geology of the Colado Geothermal Area, Pershing County, Nevada: DOE/ID/12079-8, ESL Rept. No. 38 .

Sibbett, B. S., and Nielson, D. L., 1980, Geology of the central Mineral Mountains, Beaver County, Utah: DOE/ID/28392-40, ESL Rept. No. 33,42 p.

Smith, C., 1980, Delineation of an electrical resistivity anomaly, Malpais area, Beowawe KGRA, Eureka County, Nevada: DOE/ID/12079-10, ESL Rept. No. 40.

Smith, C., 1980, Heat flow and thermal hydrology of Beowawe kGRA, Nevada: Geophysics, DOE/ID/12079-34. 


\section{0 cont.}

Smith, C., 1980, Interpretation of electrical resistivity and shallow selsmic reflection profiles, whirlwind valley and Horse Heaven Areas, Beowawe KGRA, Nevada: DOE/ID/28392-35, ESL Rept. No. 25.

Struhsacker, E. M., 1980, The geology of the Beowawe geothermal system, Eureka and Lander Counties, Nevada: DOE/ID/12079-7, ESL Rept. No. 37.

Wilson, W. R., and Chapman, D. S., 1980, Three topical reports: I. Thermal studies at Roosevelt Hot Springs, Utah; II. Heat flow above an arbitrarily dipping plane of heat sources; III. A datum correction for heat flow measurements made on an arbitrary surface: DOE/ID/12079-19.

Withrow, C., 1980, Computer plotting of drill hole geochemical data (SECTION, REV.1, User's Guide): DOE/ID/12079-6, ESL Rept. No. 36 .

Withrow, C., 1980, Computer plotting of geochemical data in plan view (PLANMAP, REV.1, User's Guide): DOE/ID/12079-3, ESL Rept. No. 35.

\section{1}

Bowman, J. R., and Rohrs, D. T., 1981, Light stable isotope studies of spring and thermal waters from the Roosevelt Hot Springs and Cove Fort/Sulphurdale thermal areas and of clay minerals from the Roosevelt Hot Springs Thermal Area: DOE/ID/12079-44.

Christensen, O. D., sibbett, B. S., and Bullett, M. J., 1981, Geochemistry of selected rock samples, Colado geothermal area, NV: DOE/ID/12079-24, ESL Rept. No. 50 .

Clement, M. D., and Chapman, D. S., 1981, Heat flow and geothermal assessment of the Escalante Desert, Southwestern Utah, with emphasis on the Newcastle KGRA: DOE/ID/12079-28.

Crecraft, H., Nash, W. P., and Evans, S. H., Jr., 1981, Late cenozolc volcanism at Twin Peaks, Utah: Geology and petrology: J. of Geophys. Res. \& J. Geol. \& Pet., DOE/ID/12079-55.

Edquist, R. K., 1981, Geophysical Investigation of the Baltazor Hot Springs known Geothermal Resource Area and the Painted Hills Thermal Area, Humboldt County, Nevada: DOE/ID/12079-29, ESL Rept. No. 54. 


\section{1 cont.}

Evans, S. H., Jr., and Brown, F. H., 1981, Summary of potassium-argon age dating: DOE/ID/12079-45.

Evans, S. H., Jr., Moore, J. N., and Adams, M. C., 1981, K/Ar ages of the Pyramid Sequence in the Vicinity of the San Emidio Geothermal Prospect, Washoe County, Nevada: DOE/ID/12079-52.

Guth, L. R., Bruhn, R. L., and Beck, S. L., 1981, Fault and foint geometry at Raft River geothermal area, Idaho: DOE/ID/12079-41.

Hulen, J. B., and Sibbett, B. S., 1981, Interpretation of drill

- cuttings from geothermal wells: DOE/ID/12079-36, ESL Rept. No. 57.

Jewe11, P. W., 1981, Geology and geothermal potential of the area north of Wells, NV: DOE/ID/12079-83, ESL Rept. No. 106.

Nash, W. P., 1981, Geologic map of the south Twin Peak-Cove Creek area, west-central, Utah: DOE/ID/12079-38.

Nutter, C., 1981, MT2D: An interactive 2-D magnetotelluric and line source modeling program (User's Gulde and Documentation for REV.3): DOE/ID/12079-31, ESL Rept. No. 55.

Nutter, C., 1981, MAG2D: An interactive 2-1/2 dimensional magnetic modeling program (User's Guide and Documentation for REV.1): DOE/ID/12079-32, ESL Rept. No. 56.

Nutter C., 1981, TCOR: A gravity terrain correction program: Univ. Utah Dept. Geol. \& Geophys. Rept. No. 65/U.

Nutter, C., 1981, SOLUPLOT to calculate equilibrium Eh-pH: Univ. Utah Dept. Geol. \& Geophys. Rept. No. 66/U.

Nutter, C., 1981, DISCRIM: Interactive program for dissecting normal/lognormal distribution: Univ. Utah Dept. Geol. \& Geophys. Rept. No. 67/U.

Nutter, C., 1981, UM-PLATE: Program to generate longitude overlay: Univ. Utah Dept. Geol. \& Geophys. Rept. No. 68/U.

Nutter, C., 1981, EQPLOT Rev. 1: Earthquake hypocenter output: Univ. Utah Dept. Geol. \& Geophys. Rept. No. 69/U.

Ross, H. P., Moore, J. N., and Glenn, W. E., 1981, The Cove FortSulphurdale KGRA - A geological and Geophysical Case study: Geophysics, ESL-81004-ABS. 


\section{1 cont.}

Ross, H. P., Glenn, W. E., and Swift, C., 1981, Reflection Seismic Surveys for Basin and Range Geothermal Areas - An Assessment: AAPG, ESL-81003-ABS.

Ruscetta, C. A., and Foley, D., 1981, Glenwood Springs Technical Conference Proceedings, Vol. I, Papers: DOE/ID/12079-39, ESL Rept. No. 59 .

Ruscetta, C. A., and Foley, D., 1981, Glenwood Springs Technical Conference Proceedings, Vol. II, Bibliography: DOE/ID/12079-40, ESL Rept. No. 60.

Sandberg, S. M., and Hulen, J. B., 1981, Exploration case history of the Monroe KGRA, Sevier County, Utah: DOE/ID/12079-40, ESL Rept. No. 60 .

Serpa, L. F., and Cook, K. L., 1981, TERRAIN: A terrain correction program for gravity data (User's Guide and Documentation for REV.0): DOE/ID/12079-26, ESL Rept. No. 52 .

Sibbett, B. S., 1981, Geology of the Tuscarora geothermal project, Elko County, Nevada: Geol. Soc. America Bull., DOE/ID/12079-33.

Sibbett, B. S., and Glenn, W. E., 1981, Lithology and well log study of Campbell E-2 geothermal test well, Humboldt House geothermal project, Pershing County, Nevada: DOE/ID/12079-27, ESL Rept. No. 53.

Sill, W. R., 1981, Self potential modeling from primary fiows: DOE/ID/12079-42.

Smith, C., Glenn, W. E., Tripp, A., and Ross, H. P., 1981, An Examination of 2-D Earth Model Resolution with the Dipole-Dipole Resistivity Method: Geophysics, ESL-81005-ABS.

Smith, C., Ross, H. P., and Edquist, R., 1981, Interpreted resistivity and IP Section, Line W1, Wahomie Area, Nevada Test Site, Nevada: ESL-81002-TR.

Struhsacker, D., 1981, An analysis of geothermal electrical power generation at Big Creek Hot Springs, Lemhi County, Idaho: DOE/ID/ 12079-37, ESL Rept. No. 58. 
1981 cont.

TrIpp, A. C., and Killpack, T. J., 1981, IPINV: A two-dimensional dipole-dipole resistivity modeling and Inversion program (User's Guide and Documentation for REV.1): DOE/ID/12079-25, ESL Rept. No. 51 .

Ward, S. H., Ross, H. P., and Nielson, D. L., 1981, Exploration strategy for high-temperature hydrothermal systems in the Basin and Range province: Am. Assoc. Petroleum Geologists Bul1., 65/1, p. 86-102. Reprinted in Energy Minerals, AAPG ... reprint Series No. 25, p. 232-248, ESL-81001-JP.

1982

Adams, M. C., 1982, The stratigraphy and structure of the McCoy geothermal prospect, Churchill and Lander counties, Nevada: DOE/ID/12079-95, ESL Rept. No. 112 .

Adams, M. C., and Capuano, R. M., 1982, Evaluation of the geothermal reservoir assoclated with Auburn and Johnson Hot Springs, Upper star Valley, Nevada: Geothermal Resources Counc11, Transactions, v. 6, DOE/ID/12079-76, ESL Rept. No. 96.

Bowman, J. R., and Cole, D. R., 1982, Hydrogen and oxygen-isotope geochemistry of cold and warm waters from the Tuscarora thermal area, Nevada: DOE/ID/12079-70, ESL Rept. No. 95.

Bowman, J. R., Nash, W. P., and Evans, S. H., Jr., 1982, Oxygen isotope geochemistry of Quaternary rhyolite from the Mineral Mountalns, Utah, U.S.A.: DOE/ID/12079-61.

Capuano, R. M., 1982, Depositional environments of trace elements in soil - Roosevelt Hot Springs, Utah:

Geol. Soc. Amer. Abstract, ESI Rept. No. 91.

Capuano, R. M., and Cole, D. R., 1982, Fluld-mineral equilibria in a hydrothermal system, Roosevelt Hot Springs, Utah:

Geochem et Cosmo. Acta, DOE/ID/12079-30.

Chapman, D., and Keho, T., 1982, A thermal resistance method for computing surface heat flow and subsurface temperatures with application to the Uinta Basin of Northeastern Utah: DOE/ID/12079-79.

Christensen, 0. D., 1982, Multielement geochemistry of 3 geothermal wells, Cove Fort/Sulphurdale geothermal area, Utah: DOE/ID/12079-80, ESL Rept. No. 101 . 
1982 cont.

Christensen, O. D., 1982, Trace element zoning in the Roosevelt Hot Springs thermal area, Utah: J. Volc. \& Geothm. Res., DOE/ID/12079-53.

Cole, D. R., 1982, Chemical and sulfur isotope variations in a thermal spring system sampled through time: Geothermal Resources Counc1l, Transactions, v. 6, DOE/ID/12079-77, ESL Rept. No. 97.

Cole, D. R., 1982, Tracing fluid sources in a complex geothermal-groundwater regime - Application of stable 1sotopes to the East Shore Area, Utah: Groundwater Journal, Univ. Utah Research Inst. Rept. DOE/ID/ 12079-51.

Evans, S. H., Jr., 1982, Summary of potassium/argon dating 1982: DOE/ID/12079-82, ESL Rept. No. 103.

Evans, S. H., Jr., and Nielson, D. L., 1982, Thermal and tectonic history, Mineral Mountains intrusive complex: Geothermal Resources Council, Transactions, v. 6, p. 15-18, DOE/ID/12079-75, ESL Rept. No. 94.

Foley, D., 1982, Road Log, Field Trip \#3 Emphasizing Geothermal Phenomena: Wyoming Geo1. Assoc., ESL-82004-ABS.

Foley, D., 1982, Hydrothermal Systems of Central Utah - A regional Perspective: Utah Geol. Assoc., ESL-82005-ABS.

Foley, D., Nielson, D. L. and Nichols, C., 1982, Road Logs: West Yellowstone to Canyon Junction, Canyon Junction to Mud Volcano - Sulphur Cauldron Area, Canyon Junction to Tower Junction to Mammoth Hot Springs, Mammoth Hot Springs to Norris Junction, Madison Junction to Old Faithful, in Reid, S. G., and Foote, D. J. (eds.), Geology of Yellowstone Park Area: Wyoming Geol. Assoc. Guidebook, ESL-82006-TR.

Foley, D., and Dorscher, M, 1982, Tables of co-located geothermal sites and BLM wilderness study areas: DOE/ID/12079-88.

Foley, D., and Nielson, D. L., 1982, Calderas and hydrothermal systems: ESL Rept. No. 104.

Foley, D., and Nielson, D. L., 1982, Geothermal systems of Yellowstone: ESL Rept. No. 105.

Glenn, W. E., and Ross, H. P., 1982, A study of well logs from Cove Fort/Sulphurdale KGRA, Millard and Beaver Counties, Utah, U.S.A.: DOE/ID/12079-62, ESL Rept. No. 75. 


\section{2 cont.}

Hulen, J. B., 1982, Stratigraphy, structure and permeability in the Redondo Creek Project Area (Valles Caldera, New Mexico): ESL-82003TR.

Hulen, J. B., and Nielson, D.. L., 1982, Stratigraphic permeability in the Baca geothermal system, Redondo Creek area, Valles caldera, NM: Geothermal Resources Council, Transactions, v. 6, p. 27-30, DOE/ID/ 12079-67, ESL Rept. No. 93 .

Hulen, J. B., and Sibbett, B. S,, 1982, Sampling and interpretation of drill cuttings from geothermal wells: SPWLA, DOE/ID/12079-78.

Kilipack, T. J., 1982, CONDUCT: A 3-D intrusive heat conduction: Univ, of Utah, Dept. of Geol and Geophys. Rept. No. $77 / \mathrm{U}$.

Mackelprang, C. E., 1982, Results of a detalled gravity survey in the Alamosa area, Alamosa County, Colorado:

DOE/ID/12079-109, ESL Rept. No. 126.

Mackelprang, C. E., 1982, Two-dimensional modeling results of telluric-magnetoteliuric data from the Tuscarora area, Elko County, Nevada: DOE/ID/12079-48, ESL Rept. No. 63.

Mackelprang, C. E., 1982, Interpretation of geophysical data from the Colado geothermal area, Pershing County, Nevada: DOE/ID/12079-58, ESL Rept. No. 71.

Mackelprang, C. E., 1982, Interpretation of dipole-dipole electrical resistivity survey, Tuscarora geothermal area, Elko County, Nevada: 12079-59, ESL Rept. No. 72.

Mackelprang, C. E., and Lange, A. L., SIbbett, B. S., and Pilkington, H. D., 1982, Interpretation of a teliuricmagnetoteliuric survey at the Tuscarora Geothermal Exploration Unit, Elko County, NV: Geophysics, ESI-82007-ABS.

Moore, J. N., Capuano, R. M., and Christensen, O. D., 1982, Geochemical indicators of a high-temperature geothermal system: DOE/ID/12079-49.

Moore, J. N., Christensen, O. D., and Bamford, R. W., 1982, Mercury as a pathfinder element in the exploration of vapor dominated geothermal systems: Geoth. Resources Council, Trans., DOE/ID/12079-43, ESL Rept. 61. 
1982 cont.

Nash, W. P., and Crecraft, H., 1982, Evolution of Quaternary magmatic system, Mineral Mountains, Utah: Interpretations from chemical and experimental modeling: DOE/ID/12079-74.

Newkirk, D., and Hohmann, G. W., 1982, Downhole electrode resistivity interpretation with 3-D models: DOE/ID/12079-47.

Nutter, C., 1982, BOTT: A 2-D sedimentary basin gravity modeling program: Univ. of Utah, Dept. of Geol. and Geophys. Rept. No. $76 / \mathrm{U}$.

Nutter, C., 1982, DIG: Menu-driven well-log digitizing software package: Univ. of Utah, Dept of Geol. and Geophys. Rept. No. $79 /$.

Nutter, C., 1982, MAP: A general purpose menu-driven program: Univ. Utah Dept. Geol. \& Geophys. Rept. No. $73 / \mathrm{U}$.

Nutter, C., 1982, G-REGION: A 2-1/2D gravity modeling program: Univ. of Utah, Dept. of Geol and Geophys. Rept. No. 82/U.

Nutter C., 1982, M-REGION: A 2-1/2D Magnetic modeling program: Univ. of Utah, pept. of Geol. and Geophys. Rept. NO. 83/U.

Nutter, C., 1982, PICKS: Interactive seismic log data input: Univ. of Utah, Dept. of Geol. and Geophys. Rept. No. 85/U.

Ross, H. P., Moore, J. N., and Christensen, O. D., 1982, The Cove Fort/Sulphurdale KGRA, a geologic and geophysical case study: Geophysics, v. 50, no. 11, DOE/ID/12079-64, ESL Rept. No. 90 .

Ross, H. P., Nielson, D. L., and Moore, J. N., 1982, Roosevelt Hot Springs geothermal system, Utah-case study:

Am. Assoc. Petroleum Geologists Bull., v. 66, no. 7, p. 879-902, DOE/ID/12079-63, ESL Rept. No. 89.

Ruscetta, C. A., 1982, Geothermal Direct Heat program, Roundup Technical Conference Proceedings, Volume I: Papers Presented: DOE/ID/1207971, ESL Rept. No. 98.

Ruscetta, C. A., 1982, Geothermal Direct Heat Program, Roundup Technical Conference Proceedings, Volume II: BIbllography of Publications: DOE/ID/12079-72, ESL Rept. No. 99. 
1982 cont.

SanFilipo, W. A., and Hohmann, G. W., 1982, Computer simulation of low frequency electromagnetic data acquisition: DOE/ID/12079-46, ESL Rept. No. 62.

Sibbett, B. S., 1982, Geology of the Tuscarora geothermal Prospect, Elko County, NV: GSA Bullet1n, ESL-82008-JP.

Sibbett, B. S., Zelsloft, J., and Bowers, R., 1982, Geology of MacFarlane's Spring Thermal Area, Nevada: Geothermal Resources Council, Transactions, ESL-82009-JP.

S111, W. R., 1982, self-potential effects due to hydrothermal convection-velocity crosscoupling: DOE/ID/12079-68.

Sill, W. R., 1982; A model for the crosscoupling parameters of rocks: $\mathrm{DOE} / \mathrm{ID} / 12079-69$.

Sill, W. R., 1982, Diffusion coupled (electrochemical) selfpotential effects in geothermal areas: DOE/ID/12079-73.

Sil1, W. R., and Killpack. T. J., 1982, SPXCPL: Two-dimensional SP modeling program of self-potential effects from crosscoupled fluid and heat flow (User's Guide and Documentation for Version 1.0): DOE/ID 12079-60, ESL Rept. No: 74 .

Smith, L., and Chapman, D., 1982, The effects of regional ground water flow on the thermal regime of a basin: DOE/ID/12079-65.

stodt, J. A., 1982, Probability distributions for magnetotellurics: DOE/ID/12079-84.

Stodt, J. A., 1982, Generalized error analysis for conventional and remote reference magnetotellurics: DOE/ID/12079-85.

Stodt, J. A., 1982, Weighted least squares estimates of the magnetoteliuric transfer functions from non-stationary data: $\mathrm{DOE} / \mathrm{ID} / 1207986$.

Stringfellow, J., 1982, Industry Coupled Case study Program Final Report: DOE/ID/12079-81, ESL Rept. No. 102 .

Wannamaker, P. E., Ward, S. H., and Hohmann, G. W., 1982 , Magnetotelluric responses of 3-D bodies in layered earths: DOE/ID/12079-87, ESL Rept. No. 106. 
1982 cont.

Wannamaker, P. E. and Hohmann, G. W., 1982, Electromagnet1c modeling of three-dimensional bodies in layered earth using. integral equations: DOE/ID/12079-50, ESL Rept. No. 64 .

Ward, S. H., I982, Resistivity, Induced polarization and self-potential methods in geothermal exploration: DOE/ID/12079-90, ESL Rept. No. 108.

We1shapt, R., Sibbett, B. S., Blackett, R. E., 1982, Lithologic Interpretation of the De Braga \#2 and \#1 geothermal we11s, Stiliwater Project, Churchili County, Nevada: DOE/ID/12079-57, ESL Rept. No. 70.

Withrow, C. A., 1982, DRAFT: Drafting aid for Initial text layout: Univ. of Utah, Dept. of Geol. and Geophys. Rept No. $80 / U$.

Withrow, C. A., 1982, PATH: Program to model distribution of species in sol.: Univ. of Utah, Dept. of Geol. and Geophys. Rept. No. $84 / \mathrm{U}$.

Withrow, C. A., 1982, RIPLEY: Program to produce mineral stability diagrams: Univ. of Utah, Dept. of Geol. and Geophys. Rept. No. $87 / \mathrm{U}$.

Withrow, C. A., and Maurer, J., 1982, PLANMAP: Interactive plan view - Geochem data, REV2: Univ. of Utah, Dept of Geol. and Geophys. Rept No. 86/U.

Zandt, G., 1982, Selsmic baseline and induction studies Rooseve1t: DOE/ID/1821, ESL Rept. No. 100.

Zeisloft, J., and Struhsacker, D. W., 1982, The geology and geothermal setting of the Magic Reservoir Area, Blaine and Camas Counties, Idaho: DOE/ID/12079-56.

\section{3}

Blackett, R., 1983, Geology and alteration of the Raft RIver Geothermal System: Geothermal Resources Counc11, Transactions, DOE/ID/12079-99, ESL Rept. No. 116.

Capuano, R. M., Adams, M. C., and Wright, P. M., 1983, Tracer recovery and mixing from two geothermal injection-backflow studies: Proceedings, 9 th Stanford Workshop on Reservoir Engineering, ESL-83008TR. 
1983 cont.

Cole, D. R., 1983, Chemical and 1sotopic Investigations of warm springs associated with normal faults: Journ. of Volcanology, v. 16, DOE/ID/12079-66, ESL Rept. No. 92.

Cole, D. R., 1983, Geothermal mineralization: The mechanism of formation of the Beowawe, Nevada siliceous sinter deposit: Amer. Jour. of Sc1., DOE/ID/12079-92, ESL Rept. No. 111.

Foley, D., 1983, State Low-Temperature Resource Assessment Program-Final Rept. for FY 82: DOE/ID/12079-114, ESL Rept. No. 131 .

Foley, D., 1983, State Coupled Report: DOE/ID/12079-124, ESL Rept. No. 149.

Foley, D., and Blackett, R., 1983, Water geochemistry of hydrothermal systems, Wood River District, Idaho: ESL-83006-TR.

Foley, D., Zeisloft, J., and Blackett, R., 1983, Hydrothermal systems of the Wood River District, Idaho: Geol. Soc. Amer, ESL-83004-ABS.

Hulen, J. B., 1983, structural control of the Baltazor Hot Springs Geothermal System, Humboldt, County, Nevada: Geothermal Resources Counc11, DOE/ID/12079-102, ESL Rept. No. 119.

Hulen, J. B., and Nielson, D. L., 1983, stratigraphy of the Bandelier Tuff and characterization of high-level clay alteration in borehole B-20, Redondo Creek, Valles caldera, NM: Geothermal Resources Counc11, Transactions, v. 7, p. 163-168, DOE/ID/12079-101, ESL Rept. No. 118.

Moore, J. N., and Adams, M. C., 1983, Geochemistry of Meager Creek Geothermal Field, British Columbia, Canada: Geothermal Resources Council, Transactions, DOE/ID/12079-100, ESL Rept. No. 117.

Newman, G., 1983, Detection of conductive bodies in a layered earth using the magnetoteliuric method: Application of s111c1c magma bodies: DOE/ID/12079-96, ESL Rept. No. 113.

Nielson, D. L., and Hulen, J. B., 1983, Geologic model of the Baca geothermal reservolr, Valles caldera, New Mexico: Proceedings Ninth Workshop on Geothermal Reservoir Engineering, Stanford University, p. 145-150, ESL-83002-TR. 
1983 cont.

Sibbett, B. S., 1983, structural control and alteration at Beowawe KGRA, Nevada: Geothermal Resources Council, Transactions, ESL-83007-JP.

S111, W. R., 1983, Interpretation of SP measurements during injection tests at Raft River, Idaho: DOE/ID/12079-103, ESL Rept. No. 120.

S111, W. R., 1983, Resistivity measurements before and after injection test No. 5 at Raft River KGRA, Idaho: DOE/ID/12079-104, ESL Rept. NO. 121 .

Sorey, M., Reed, M., Foley, D., and Renner, J., 1983, Low-temperature geothermal resources in the central and eastern United States: USGS, ESL-83005-TR.

Struhsacker, E., 1983, An evaluation of exploration methods for low-temperature geothermal systems in the Artesian City Area, Idaho: Geol. Soc. Amer., DOE/ID/12079-91, ESL Rept. No. 110.

Struhsacker, D. W. Jewell, P. W., Zelsloft, J., and Evans, S. H., Jr., 1983, The geology and geothermal setting of the Magic Reservoir Area, Blaine and Camas Counties, Idaho: DOE/ID/12079-106, ESL Rept. No. 123.

Thussu, J., 1983, Preliminary geothermal assessment of the Tattapani Thermal Area, Madya Prodesh, India: Geothermal Resources Council, Transactions, DOE/ID/12079-98, ESL Rept. No. 115.

Thussu, J., Moore, J. N., and Capuano, R. M., 1983, Preliminary geothermal assessment of the Tattapani thermal area, Madya Prodesh, India: Geothermal Resources Counc11, Transactions, ESL-83001-JP.

Wannamaker, P. E., 1983, Deep resistivity structure in southwestern Utah and its geothermal significance: DOE/ID/12079-89, ESL Rept. No. 109.

Ward, S.H., 1983, Controlled source electromagnetic methods in geothermal exploration: DOE/ID/12079-97, ESL Rept. No. 114.

Ward, S. H., 1983, Geophysical studies of active geothermal systems in the northern Basin and Range: DOE/ID/12079-108, ESL Rept. No. 125. 


\section{3 cont.}

Zeisloft, J., Foley, D., and Blackett, R, 1983, Water geochemistry of hydrothermal systems, Wood River District, Idaho: DOE/ID/12079-107, ESL Rept. No. 124.

1984

Adams, M. C., 1984, Geochemistry of the Wendel-Amedee geothermal system, CA: Geothermal Resources Council, Transactions, ESL84010-JP.

Capuano, R. M., 1984, Chemlcal analyses of water samples collected during injection-backflow testing at Raft River, Idaho: DOE/ID/ 12079-112, ESL Rept. No. 129.

Cole, D. R., and Ravinsky, L., 1984, Hydrothermal alteration zoning in the Beowawe Geothermal System, Eureka and Lander Counties, Nevada: Economic Geology, DOE/ID/12079-121, ESL Rept. No. 138.

Foley, D., 1984, State Low-Temperature Resource Assessment Program: DOE/ID/12079-111, ESL Rept. No. 128.

Foley, D., 1984, State Low-Temperature Resource Assessment Program - Final Rept. for FY 83: DOE/ID/12079-115, ESI Rept. No. 132 .

Foley, D., and Zeisloft, J., 1984, Geothermal resources of the Balcones Ouachita Trend, Central TX: AAPG, ESL 84009-ABS.

Kroneman, R. L., Yorgason, K., and Moore, J. N., 1984, Preferred methods of analysis for chemical tracers in moderate- and high-temperature geothermal environments: DOE/ID/12079-128, ESL-84001-TR.

Moore, J. N., 1984, The geochemistry and mineralogy of The Geysers - A reconnalssance study: DOE/ID/12079-119, ESL Rept. No. 136 .

Nielson, D. L.. 1984, Final Report - Geothermal exploration and geothermal power plant update for Ascension Island, South Atlantic Ocean: DOE/ID/12079-118, ESL Rept. 135.

Nielson, D. L., and Hulen, J. B., 1984, Internal geology and evaluation of the Redondo Dome, Valles Caldera, New Mexico: Journal of Geophysical Research, v. 89, p. 8695-8711, DOE/ID/12079-105, ESL Rept. No. 122 . 
1984 cont.

Ross, H. P., Mackelprang, C, E., and Dajany, S, F., 1984, Supplemental electrical resistivity surveys, Ascension Island, South Atlant1c Ocean: DOE/ID/12079-123, ESL Rept. No. 142.

Sibbett, B. S., 1984, Geothermal gradient drilling and measurements, Ascension Island, South Atlantic Ocean: DOE/ID/12079-117, ESL Rept. No. 134.

Sibbett, B. S., and Capuano, R. M., 1984, Potential for low-temperature geothermal resource near Mackay, Idaho: DOE/ID/12079-120, ESL Rept. No. 137.

Ward, S. H., Foley, D., Moore, J. N., Nlelson, D. L., Ross, H. P., and Wright, P. M., 1984, Exploration strategies for regional assessment of hydrothermal resources: ESL-84006TR.

Wright, P. M., Capuano, R. M., Adams, M. C., and Moore, J. N., 1984, Uses of geochemistry with injection-backflow testing in geothermal reservoir studies: Geothermal Resources Council, Transactions, v. 8, ESL-84002-JP.

Zeisloft, J., 1984, Case study of the clty of Alamosa geothermal project of the User-Coupled Confirmation Drilling Program: DOE/ID/12079-113, ESL Rept. No. 130.

Zeisloft, J., 1984, Geothermal evaluation of the Hosston Formation, Lackland AFB, San Antonio, Texas: DOE/ID/12079-110, ESL Rept. No. 127.

Zeisloft, J., 1984, Lackland AFB geothermal summary report Phase I: DOE/ID/12079-116, ESL Rept. No. 133.

Zeisloft, J., Slbbett, B. S., and Adams, M. C., 1984, Case study of the Wendel-Amedee KGRA exploration drililing: DOE/ID/12079-127, ESL Report No. 162 .

\section{5}

Adams, M. C., 1985, Tracer stability and chemical changes in an injected geothermal fluid during East Mesa injection testing: Proceedings, stanford Workshop on Reservoir Engineering, ESL-85013-TR.

Adams, M. C., and Moore, J. N., 1985, Fluld flow in volcanic terrains - Hydrogeochemistry of the Meager Mountain thermal system: ESL Rept. No. 151. 
1985 cont.

Adams, M. C., and Moore, J. N., 1985, Geothermal systems in mountainous terraines: an example from Meager Mountain: American Jour. of Science.

Adams, M. C., and Moore, J. N., 1985, Development and application of tracers: Examples of field and experimental studies: DOE/ID/12079129, ESL-85017-JP.

Aleinkoff, J. N., Nielson, D. L., Hedge, C. E., and Evans, S H., Jr.. 1985, Geochronology of Precambrian and Oligocene rocks in the Mineral Mountains, south-central Utah: U.S. Geol. Survey Bull. 1622, ESL-85005-JP.

Beasley, C. W., and Ward, S. H., 1985, 3-D mise-a-la-masse modeling applied to mapping fracture zones: DOE/SAN/121963, ESL Rept. No. 143.

Final Progress Report - Research and Technology Development for Geothermal Reservolr Definition Program, 1985: DOE/SAN/12196-10, ESL Rept. No. 155.

Foley, D., and street, L., 1985, Geothermal systems of the Snake River Plain, Idaho batholith and Northern Rocky Mountain transition zone: Geol. Soc. Amer, ESL-85011-ABS.

Goff, F., Nielson, D. L., Wollenberg, H, 1985, Investigation of Magma-hydrothermal systems: CSDP proposal for the Valles caldera, New Mexico: Continental Scientific Driliing Program Workshop, Houston, p. 50-52.

Hulen, J. B., 1985, Significance of surficial alteration in the Coso geothermal area: ESL-85007-TR.

Hulen, J. B., and Nielson, D. L., 1985, Hydrothermal alteration in the Baca geothermal system, Redondo Dome, Valles caldera, New Mexico: Journal Geophysical Research, DOE/SAN/12196-6, ESL Rept. No. 145.

Hulen, J. B., Nielson, D. L., 1985, Altered tectonic and hydrothermal breccias in Corehole vC-1, Valles caldera, New Mexico: 1985 AGU fall meeting abs.

Hulen, J. B., and N1elson, D. L, 1985, Subsurface hydrothermal alteration in the Baca geothermal system, Redondo Dome, Valles caldera, New Mexico: ESL-85002-ABS. 


\section{5 cont.}

Moore, J. N., Adams, M. C., and Stauder, J., 1985, Geologic and geochemical investigations of the Meager Creek geothermal system, British Columbia, Canada: DOE/SAN/12196-7, ESL Rept. No. 147 .

Nielson, D. L., 1985, Predictive structural models for the development of fracture permeability in geothermal areas: LBL Fracture Definition Workshop, DOE/SAN/12196-15, ESL Rept. No. 160.

Nlelson, D. L., 1985, Quarterly Progress Report for U.S. Dept. of Energy Geothermal Reservolr Definition Program - June 1, 1984-Sept. 30, 1984: DOE/SAN/12196-11, ESL Rept. No. 156.

Nielson, D. L., 1985, Quarterly Progress Report for U.S. Dept. of Energy Geothermal Reservolr Definition Program - January 1, 1985-March 31, 1985: DOE/SAN/12196-12, ESL Rept. No. 157.

Nielson, D. L., 1985, Quarterly Progress Report for U.S. Dept. of Energy Geothermal Reservoir Definition Program - April 1 , 1985 - June 30, 1985: DOE/SAN/12196-16, ESL-85022-PR.

Nielson, D. L., Evans, S. H., Jr., and Sibbett, B. S., 1985, Magmatic, structural and hydrothermal evolution of the Mineral Mountains Intrusive Complex, Utah: Geological Society of America Bulletin, ESL-85006-JP.

Nielson, D. L., and Goff, F., 1985, Sclentific driliing in a vapor-dominated geothermal system, VC-2A, Sulphur springs, Valles caldera, New Mexico: 1985 AGU fall meeting abs.

Nielson, D. L., and Hulen, J. B., 1985, Observations in an active hydrothermal system through deep drilling, Valles caldera, New Mexico in Observation of the Continental Crust through Drilling I: Elsevier, DOE/SAN/12196-1, ESL Rept. No. 140.

Nielson, D. L., and Hulen, J. B., 1985, Results of deep drliling in the Valles caldera, New Mexico: DOE/SAN/12196-5, ESL Rept. No. 146.

Nielson, D. L., and Hulen, J. B., 1985, structure and stratigraphy of the Redondo Dome, Valles caldera: ESL-85003-ABS.

Nielson, D. L., and Moore, J. N., 1985, Geological and geochemical techniques for fracture definition in geothermal reservoirs: DOE/SAN/12196, ESL-85018-TR, presented at DOE/DC Program Review. 


\section{5 cont.}

Ross, H. P., and Ward, S. H., 1985, Borehole electrical geophysical methods - A review of the state-of-the-art and preliminary evaluation of the application to fracture mapping in geothermal systems: DOE/SAN/12196-2, ESL Rept. No. 141 .

Ross, H, P., and Moore, J. N., 1985, Geophysical investigations of the Cove Fort-Sulphurdale geothermal system, Utah: Geophysics, ESL-85001-JP.

Sibbett, B. S., 1985, Fleld check of photogeological map of proposed NPR site E and viclnity, INEL, Idaho: DOE/ID/12079-122, ESL Rept. No. 139.

Sibbett, B. S., 1985, Geoproducts Wen-2 We11, Wendel-Amedee, CA: DOE/ID/12079-125, ESL Rept. No. 152 .

Wannamaker, P.E., 1985, Electrical conductivity of waterundersaturated crustal melting: J. Geophys. Research. NSF Contract No. EAR-8417765, ESL-85023-JP.

Wannamaker, P. E., 1985, Very low-frequency magnetotellurlc and dipole-dipole responses of three-dimensional thin-layer resistivity structure modeled using finite elements: DOE/SAN/12196-14, ESL Rept, No. 159.

Wannamaker, P. E., stodt, J. A, and RiJo, L. 1985, PW2D-Finite element program for solution of magnetotelluric responses of Two-dimensional earth resistivity structure: User Documentation: DOE/SAN/12196-13, ESL Rept. No. 158.

Wannamaker, P. E., Stodt, J. A., and RIJo, L., 1985, A stable finite element solution for 2-dimensional magnetotelluric modeling: ESL85019-JP, NSF Contract No. EAR-8500248, Geophys. J. of the Royal Astronomical society.

Ward, S. H., and Moore, J. N., 1985, Indications of mineral zoning in a fossil hydrothermal system at the Meager Creek Prospect, B.C., Canada from Induced polarization: DOE/SAN/12196-9, ESL Rept. No. 154.

Woodruff, C., and Foley, D., 1985, Thermal regimes of the Balcones/Quachita trend, Texas: Gulf Coast Assoc. Geological Societies, ESL-85012-ABS. 
1985 cont.

Wright, P. M., 1985, Application of geophysics for concealed hydrothermal systems in volcanic terrains: Geothermal Resources Council, Transactions, v. 9, ESL Rept. No. 150.

Wright, P. M., 1985, Applications of geochemistry to problems in geothermal injection: DOE/WA Program Review, DOE/ID/12079-133, ESL85034-TR.

Wright, P. M., 1985, In-Situ Leaching and Solution Mining - state of the Art and Recommended Research - Summary Report, Phase I, to U.S. Bureau of Mines and industry participants: ESL-85031-TR.

Appendix 1 - Geologlcal Characterization for solution Mining and Direct Leaching, by Jeffrey B. Hulen, W1lliam C. Larson, william P. Nash, Richard L. Nielsen, Dennis L. Nielson and Philitp M. Wright.

Appendix 2 - Chemistry, by Michael C. Adams, John A. Apps, Regina M. Capuano, David R. Cole, Charles L. Kusik, Donald Langmuir, and Milton E. Wadsworth.

Appendix 3 - Fracturing and Rubbilzation, by Dennis V. D'Andrea, Wayne O. Ursenbach, Howard M. Wells, and Stephen R. Winzer.

Appendix 4 - Fluld Flow Management, by Steven E. Follin, Larry W. Lake, Subir Sanyal, Ronald C. Schroeder, Devraj Sharma, and Phillip M. Wright.

In-Situ Leaching and solution Mining - Evaluation of state of the Art - Bibliography.

Wright, P. M., and Ward, S. H., 1985, Borehole geophysical techniques for defining permeable zones in geothermal systems: Geothermal Resources Counc11, DOE/WA Prog. Review, ESL-85014-JP.

Wright, P. M., Ward, S. H., Ross, H. P., and West, R., 1985, State of the art - geophysical exploration for geothermal resources: Geophysics, ESL-85015-JP.

Yang, $F$, 1985, Short Note: On sensitivity of surface-toborehole resistivity measurements to the attitude and the depth to center of a three-dimensional spheroid: DOE/SAN/12196-4, ESL Rept. 144.

Zelsloft, J., and Sibbett, B. S., 1985, City of Alamosa, Colorado, Alamosa \#1 geothermal test well UCCDP project case study: DOE/ID/ 12079-126, ESL Rept. No. 161 . 


\section{5 cont.}

Zhao, J. X., RIJo, L., and Ward, S. H., 1985, Evaluation of the ratio of signal-to-nolse in cross-borehole electrical surveys: DOE/SAN/121968, ESL Rept. No. 148.

Adams, M. C., Ahn, J. H., Bentley, H., Moore, J. N., and Veggeberg, S., 1986, Derivitized hydrocarbons as geothermal tracers: Geothermal Resources Counc11, DOE/ID/12489-2.

Adams, M. C., Ahn, J. H., Moore, J. N., and Veggeberg, S., 1986, Tracer developments: Results of experimental studies: Proceedings, 11th Workshop on Geothermal Reservolr Engineering, Stanford University, January 21-23, ESL Rept. No. ESL-86001-TR.

Ballentyne, J., and Moore, J. N., 1986, Arsenic geochemistry in geothermal systems: Geochemica et Cosmochemica, Acta, DOE/ID/12489-5.

Beasley, C. W., and Ward, S. H., 1986, Three-dimensional mise-a-la-masse modeling applied to mapping fracture zones, Geophysics, v. 51, p. 98-113.

Echols, D., Hulen, J. B., and Moore, J. N., 1986, Surficial alteration and spring deposits of the Wheeler mercury prospect, with initial results from wheeler corehole G416, Coso geothermal area, California: Geothermal Resources Council, DOE/SAN/12196-20.

Green, D. J., and Ward, S. H., 1986, Report on preliminary design for multi-array borehole electrical geophysical method: DOE/SAN/1219623.

Howell, J., and Chapman, D., 1986, Analysis of temperature-time data from $3 \mathrm{~m}$ driliholes at Crystal Hot Springs, Utah:

Univ. Utah Res. Inst. Rept. DOE/ID/12079-130, ESL-86006-TR.

Hulen, J. B., et al., 1986, stockwork molybdenum mineralization In an active geothermal system, Sulphur Springs area, Valles caldera, New Mexico: DOE/OBES ( to be submitted to Geology).

Hulen, J. B., and Nielson, D. L., 1986, stratigraphy and hydrothermal alteration in well Baca-8, sulphur springs area, Valles caldera, New Mexico: Geothermal Resources Counc11, DOE/SAN/12196-19.

LeBrecque, D., and Ward, S. H., 1986, Evaluation of borehole MMR for fracture detection: DOE/SAN/12196-24. 
1986 cont.

Moore, J. N., and Adams, M. C., 1986, Thermal and chemical evolution of the caprock in the Salton Sea geothermal field, California: DOE/ SAN/12196-22.

Moore, J. N., and Nlelson, D. L., 1986, Geological and geochemical techniques for mapping fractures and fluid flow patterns in geothermal reservoirs: presented at 56th California Reglonal Meeting, Society of Petroleum Engineers, Oakland, CA, April 2-4.

Nash, W. P., 1986, Distribution, lithology and ages of late cenozoic volcanism on the eastern margin of the Great Basin, West-Central Utah: Univ. Utah Res. Inst. Rept. DOE/SAN/12079-131, ESL-86007-TR.

Nielson, D. L., 1986, Quarterly Progress Report for U.S. Department of Energy Reservoir Definition Program - June 30, 1985-Sept. 30, 1985 and Annual Report Sept. 30-Dec. 31, . 1985, DOE/SAN/12196-17, ESL86005-PR.

Nielson, D. L., 1986, Quarterly Progress Report for U.S. Department of Energy Reservolr Definition Program, Jan. 1, 1986-Mar. 31, 1986, Univ. Utah Res. Inst. Rept., DOE/SAn/12196-25.

Nielson, D. L., 1986, Quarterly Progress Report for U.S. Department of Energy Reservolr Definition Program, Apri1 1, 19.86-June 30, 1986, Univ. Utah Res. Inst. Rept., DOE/SAN/12196-26.

Sibbett, B. S., 1986, strato-volcano model/geothermal systems: Univ. Utah Res. Inst. Rept., DOE/ID/12489-4.

West, R. C., and Ward, S. H., 1986, The borehole controlledsource audiomagnetotelluric response of a three-dimensional fracture zone: Geophysics, ESL-86012-JP.

Wright, P. M., 1986, Geothermal development in Utah and status of the U.S. geothermal industry: Univ. Utah Res. Inst. Rept. for Interstate 011 Compact Comm.

Wright, P. M., 1986, status of the geothermal industry and recommendations for hydrothermal research, Geothermal Resources Council Rept. and Univ. Utah Res. Inst. Rept.

Wright, P. M., 1986, Geothermal energy - An overview of occurrence and exploration: Geothermal Resources Council Special Paper, ESL-86003-JP. 
Adams, M. C., and Moore, J. N., 1987, Hydrothermal alteration and fluid geochemistry of the Meager Mountain geothermal system, Amer. Jour. Sc1.

Allison, M. Lee, and Nielson, Dennis L., 1987, Survey of borehole breakouts from active geothermal systems: EOS, v. 68 , p. 1460-1461.

Boyer, Steven E., and Allison, M. Lee, 1987, Estimates of extensions. In the Basin and Range Province: GSA Abs. with Program, v. 19, n. 7, p. 597.

Hulen, J. B., and Nielson, D. L., 1987, Brecclas of CSDP Corehole VC-1 and a model for hydrothermal brecclation, Jour. Geophys. Res.

Hulen, J. B., Nlelson, D. L., Goff, F., Gardner, J. N., and Charles, R. W., 1987, Molybdenum mineralizatio in an active geothermal system, Valles caldera, New Mexico: Geology, 15, p. 748-752.

Hulen, J. B., Nielson, D. L., Goff, F., and Gardner, J. N., 1987, Hydrothermal alteration and molybdenum mineralization in the active geothermal system at sulphur Springs, Valles caldera, New Mexico (abs.) EOS, 68, p. 469 .

Moore, J. N., and Adams, M. C., 1987, Early diagnetic mineralization in the Salton Sea geothermal system, California: GRC.

Moore, J. N. and Adams, M. C., 1987, Evolution of the thermal cap in two wells from the Salton sea geothermal systems, California.

Nielson, D. L., and Hulen, J. B., 1987, Hydraullc fracturing and hydrothermal brecciation in active geothermal systems: Geoth. Res. counc., Trans., 11, p. 473-478.

Ross, H. P., 1987, State Cooperatlve Program, Annual Report for 1986, DOE-AC07-85ID12489.

Wannamaker, P. E., stodt, J. A., and Rijo, L., 1987, A stable finite element solution for two-dimensional magnetotelluric modeling: Geophy. J. Roy. Astr. Soc., 88, 277-296. 
1987 cont.

Wannamaker P. E., stodt, J. A., and R1Jo, L., 1987, PW2D: Finite element program for solution of magnetotelluric responses of two-dimensional earth resistivity structure: User documentation, revised edition, Dept. of Energy Rep. DOE/SAN12196-13, $40 \mathrm{p}$.

Wright, P. M., 1986, Final Report for DOE Contract DE-ACO780ID12079: Univ. Utah Res. Inst. Rept. DOE/ID/12079-132, ESL-86010-TR.

Wright, P. M., and Nielson, D. L., 1987, Electrical resistivity anomalies at Newberry volcano, Oregon: Comparison with alteration mineralogy in GEO Corehole $\mathrm{N}-1$, Geothermal Resources Counc11, DOE/ID/12489-3.

Wright, P. M., 1987, status of U.S. Geothermal Industry and Recommendations for Hydrothermal Research: GRC.

Wright, P. M., 1987, The nature and geologic characteristics of geothermal resources, abs., AAPG meeting.

Zhao, J. X., RIJO, L., and Ward, S. H., 1987, The effects of geologic noise on cross-borehole electrical surveys; Geophysics.

\section{8}

Adams, M. C.. Lemieux. M. M., Moore, J. N., and Johnson, S. D., 1988, Fluid chemistry and hydrology of the Heber geothermal system, Californla: GRC, DE-AC07-8512489, ESL-88010-JP.

Allison, M. L., 1988, Seismicity of Ascension Island, ESL/UURI Rept., DOE-ID/85107, ESL-88003-TR.

Allison, M. L., and Nielson, D. L., 1988, Application of borehole breakout studies to geothermal exploration and development: An example from Cove Fort-Sulphurdale, Utah, GRC, DE-AC07-85ID12489, ESL-8808-JP.

Ballantyne, J. M., and Moore, J. N., 1988, A new 1111te geothermometer, Stanford Geothermal Reservoir Engineering Workshop (in press), ESL-8803-JP.

Ballantyne, J. M. and Moore, J. N., 1988, Axsenic geochemistry in geothermal systems. Geochimica et Cosmochimica Acta. V. 52, pp. 475-483, ESL-88014-JP. 
1988 cont.

Ballantyne, J. M., 1988, A sheet zIpper theory of smectite 1liltization: Implications for and evidence from, electron Imaging, $x$-ray diffraction, mineral chemistry, hydrothermal fluids, kinetics and thermodynamics, (in prep.), ESL-88015JP.

Beasley, C. W., and Ward, S. H., 1988, Cross-borehole resistivity Inversion; abs, SEG, ESL-88003-ABS.

Hulen, J. G., Gardner, J. N., Nlelson, D. L., and Goff, F., 1988, stratigraphy, structure, hydrothermal alteration and ore mineralization encointered in CSDP corehole VC-2A, sulphur Springs area, Valles caldera, New Mexico: Univ, of Utah Res. Inst., Earth Sc1. Lab., Rept. No. ESL-88001-TR (DOE/ER/13555-1), 39 p.

Hulen, J. B., and Nielson, D. L., 1988, Hydrothermal brecciation in the Jemez fault zone, Valles caldera, New Mexico Results from CSDP corehole.VC-1: J. Geophys. Res., v. 93, p. 6077-6089, ESL-88016-JP.

Hulen, J. B., and Nielson, D. L., and the Valles scientific Drilling Team, 1988, Site-speciflc science plan for Continental Scientific Driliing Program corehole VC-2B: Univ. of Utah Res. Inst. and Los Alamos Nat. Lab. Rept. (in prep.), ESL-88004-TR.

Hulen, J. B. and Nielson, D. L., 1988, Clay Mineralogy and zoning In CDSP corehole VC-2A: Further evidence for Collapse of isotherms in the Valles caldera, New Mexico, GRC, DE-AC0785-12489, ESL-88013-JP.

Hulen, J. B., Little, T. M., and Nielson, D. L., 1988 , Intracaldera clastic deposits as guides to evolution of the Valles caldera complex and assoclated hydrothermal systems, Jemez Mountains, New Mexico: J. Geophys. Res., In review; ESL-88017-JP.

LaBrecque, D. J., and Ward, S. H., 1988, The effect of well casing on 3-D interpretation of borehole resistivity data; abs., SEG, ESL-88001-ABS.

LaBrecque, D, J., and Ward, S. H, 1988, Two-dimensional inversion of cross-borehole resistivity data using moveable boundaries; abs., SEG, ESL-8802-ABS.

LaBrecque, D. J., 1988, Design of a borehole-to-surface resistivity survey for the Magma Energy deep exploration we11, GRC, DE-AC07-85ID12489, ESL1-88011-JP. 
1988 cont.

Lemieux, M. M., Wright, P. M., and Moore, J. N., 1988, Research Coring in the Cascades: A status report, GRC, DE-AC0785ID12489, ESL-880012-JP.

Nielson, D. I. and Ballantyne, J. M., 1988, Hydrothermal processes: Advances in Geothermal Reservoir Technology Research in Progress (in prep.), ESL-88018-JP.

Nielson D. L., Hulen, J. B., Goff, F, and Gardner, J. N., 1988, Scientific exploration of an active magma-hydrothermal system in the Valles caldera, New Mexico, through drilling L-III: New York, Springer-Verlag, in press, ESL-88019-JP.

Tr1pp, A., 1988, Group theoretic reduction of the electromagnetic impedance matrix for large-contrast symmetric prisms in a layered earth, submitted to IEEE, ESL-88006-JP.

Tripp, A. C. and Klein, J. D., 1988, Departure curves for Induced polarization well logging, March-April Issue, The Log Analyst.

Tripp, A. C., Klein, J. D., Halverson, M. D., and Kingman, J., 1988. IP Interpretation using electromagnetic coupling data - a fleld example (in prep.).

Tripp, A. C...Limieux, M. M., Wright, P. M., and Moore, J. N., 1988, Induced polarization response of related Cascade core samples: GRC, DE-ACO7-8512489, ESL-88009-JP.

Young, C. T., Booker, J. R., Fernandez, R., J1racek, G. R., Martinez, M., Rogers, J. C. . Stodt, J. S., Waff, H. S., and Wannamaker, P.E., 1988, Verification of five magnetoteliuric systems in the mini-EMSLAB experiment: Geophysics, 53, 553557.

Wannamaker, P. E., fourth author in the EMSLAB Group, 1988, The EMSLAB electromagnetic sounding experiment: EOS Trans., 69, (7), 89, 98-99.

Wannamaker, P. E., and fourteen coauthors, 1988, Magnetotelluric observations across the Juan de Fuca subduction system and its tectonic Implications: J. Geophys. Res., in prep., ESL88007-JP.

Wannamaker, P. E., and fourteen coauthors, 1988, Conductivity cross section through the Juan de Fuca subduction system and its tectonic implications: J. Geophys. Res., in prep. 


\section{8 cont.}

Wannamaker, P. E., 1988, Magnetotelluric profile across Long Valley caldera, in Proc. of the Symposium on the Long Valley caldera: a pre-drilling data review, ed. by N. L. Goldstein, LBL rep. 23940, 150-158, ESL-88001-PR.

Ward, S. H., 1988, The resistivity and Induced polarization methods (in prep.), ESL-88004-JP.

Ward, S. H., and West, R. C., 1988, The borehole transient electromagnetic response of a three-dimensional fracture zone in a conductive half-space (In prep.),ESL-88002-JP.

West, R. C., and Ward, S. H., 1988, The borehole controlledsource audiomagnetotelluric response of a three-dimensional fracture zone, Geophysics, v. 53.

Wright, P. M., 1988, Forecast and outlook for geothermal energy, 1988-1998, Presentation to Annual AAPG meeting in Houston, ESL-88005-JP. 


\section{GEOTHERMAL SAMPLE LIBRARY INAENTORY}

The locations of areas represented by significant drill samples at the Geothermal Sample Library are shown in Figure 3. An inventory of all samples curated at the Library follows.

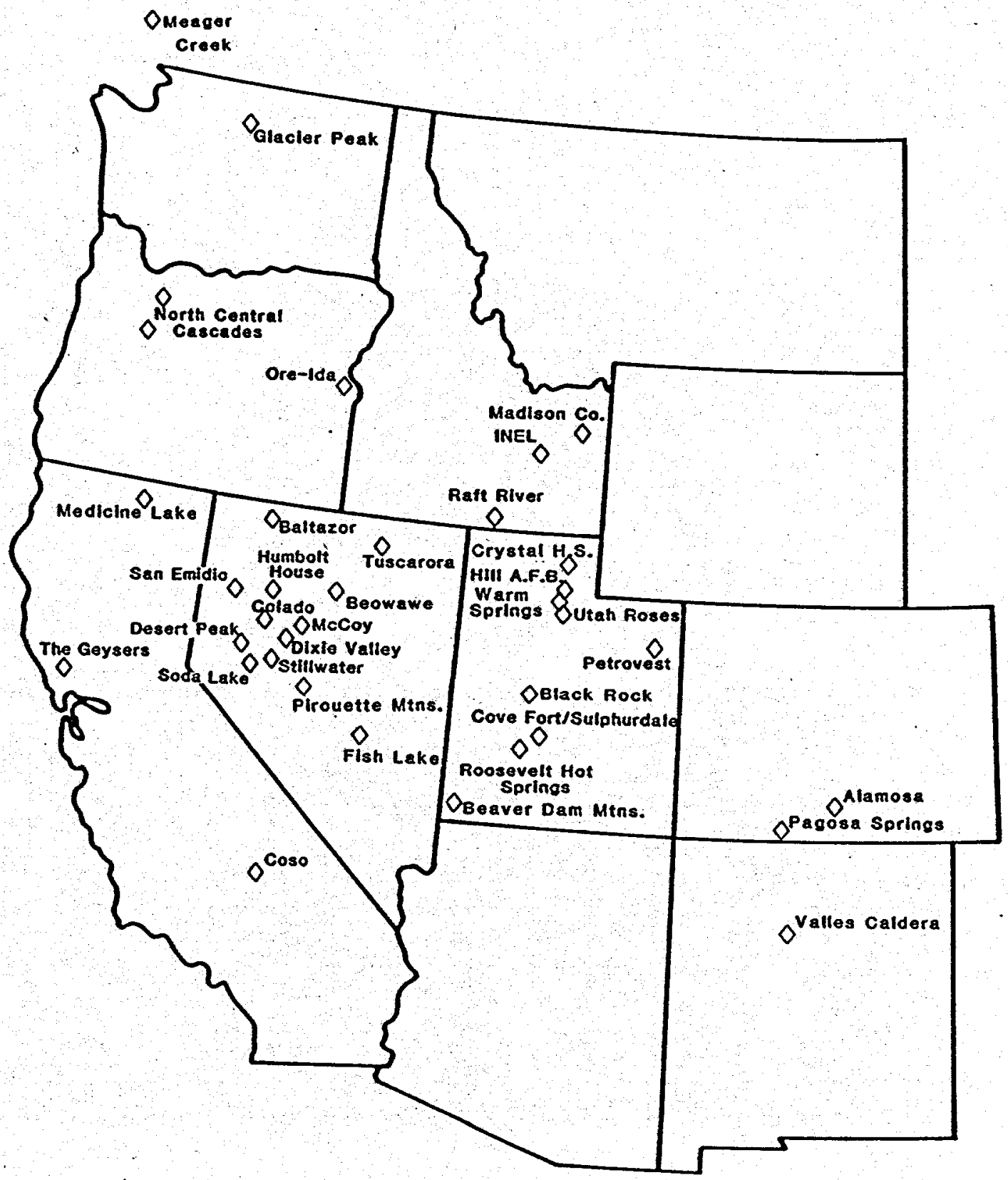

Figure 3. Location Map - Drill Hole Samples in Geothermal Sample Lịbrary 


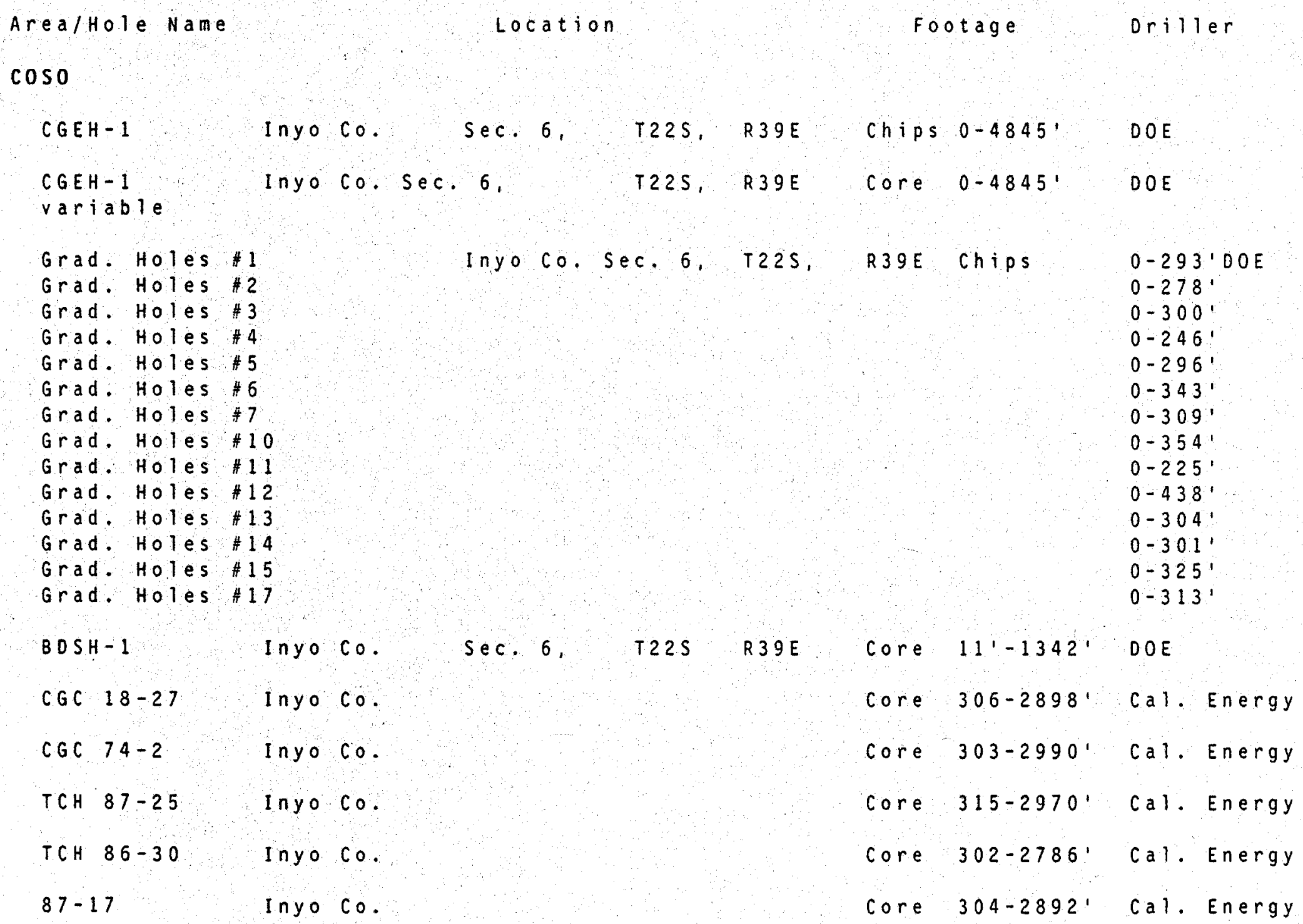




\section{Area/Hole Name}

$\cos 0$

\section{Location}

$\sec 6$

Inyo Co.sec. 6 ,
Footage

$\begin{array}{ll}\text { Chips } 0-4845^{\circ} & \text { DOE } \\ \text { Core } 0-4845^{\circ} & \text { DOE }\end{array}$

$R 39$
Inyo Co, Sec, 6, T22S,

Grad. Holes 3

Grad. Holes \#4

Grad.Holes 5

Grad.Holes 6

Grad. Holes $\# 7$

Grad. Holes \#10

Grad. Holes \#11

Grad. Holes \#12

Grad.Holes \#13

Grad.Holes \#14

Grad. Holes \#15

Grad.Holes \#17

$\begin{array}{ll}\text { BOSH-1 } & \text { Inyo Co. } \\ C G C 18-27 & \text { Inyo Co. } \\ C G C 74-2 & \text { Inyo Co. } \\ \text { TCH } 87-25 & \text { Inyo Co. } \\ \text { TCH } 86-30 & \text { Inyo Co. } \\ 87-17 & \text { Inyo Co. }\end{array}$

Sec. 6, T22S Rุ39E

Core

Core

Core $315-2970^{\circ}$

Core $302-2786$

core $304-2892^{\prime}$

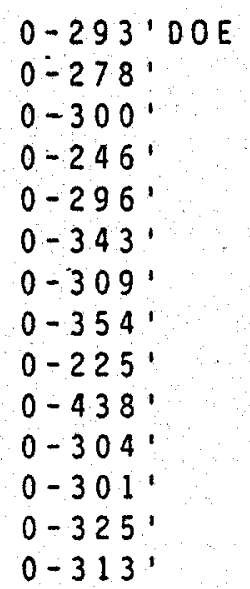

DOE

Ca1. Energy

Ca 1: Energy

Ca 1. Energy

Ca 1. Energy

Cal. Energy 
r

C 1
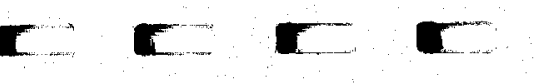

CALIFORNIA cont.

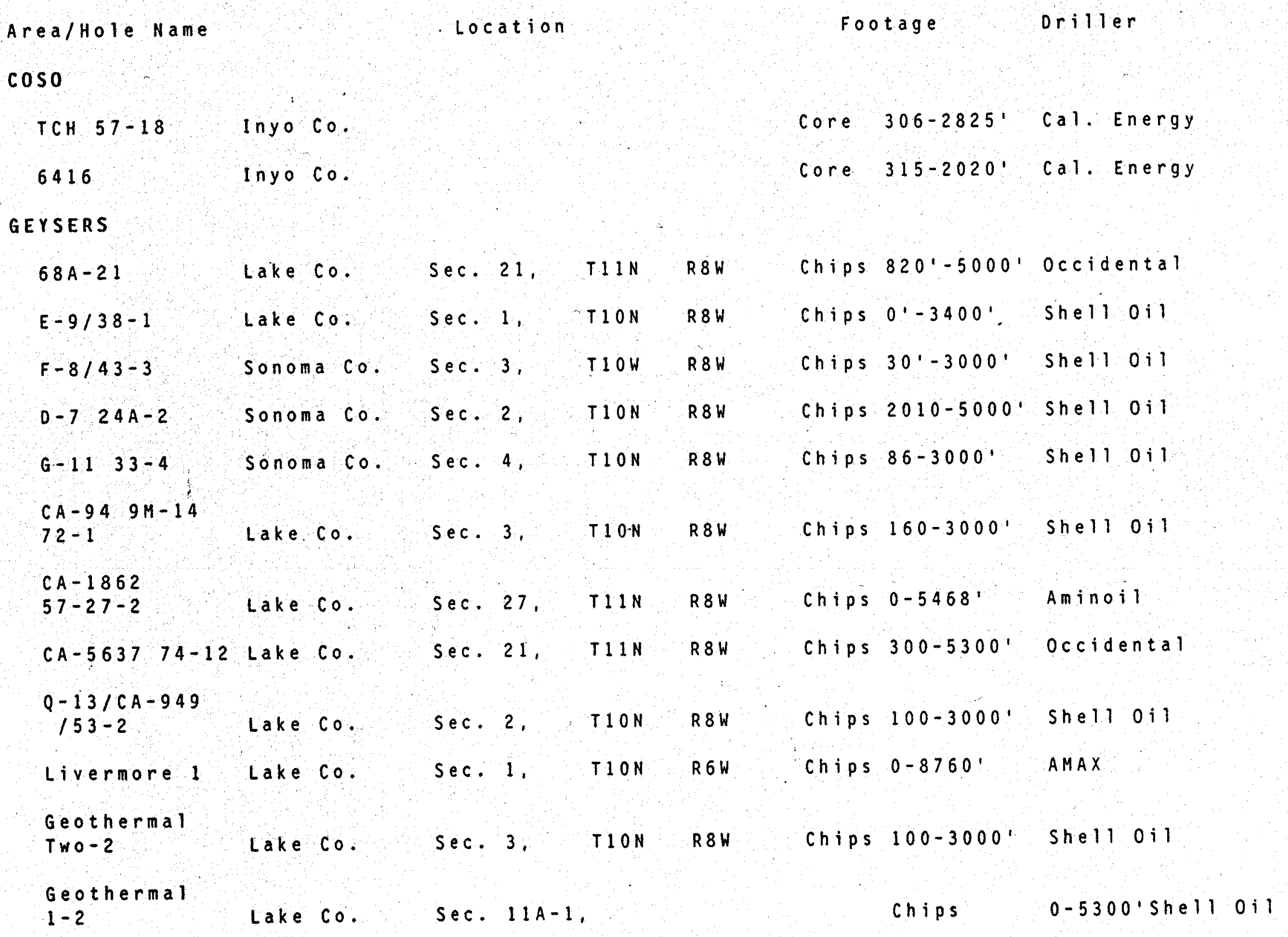


CALIFORNIA cont.

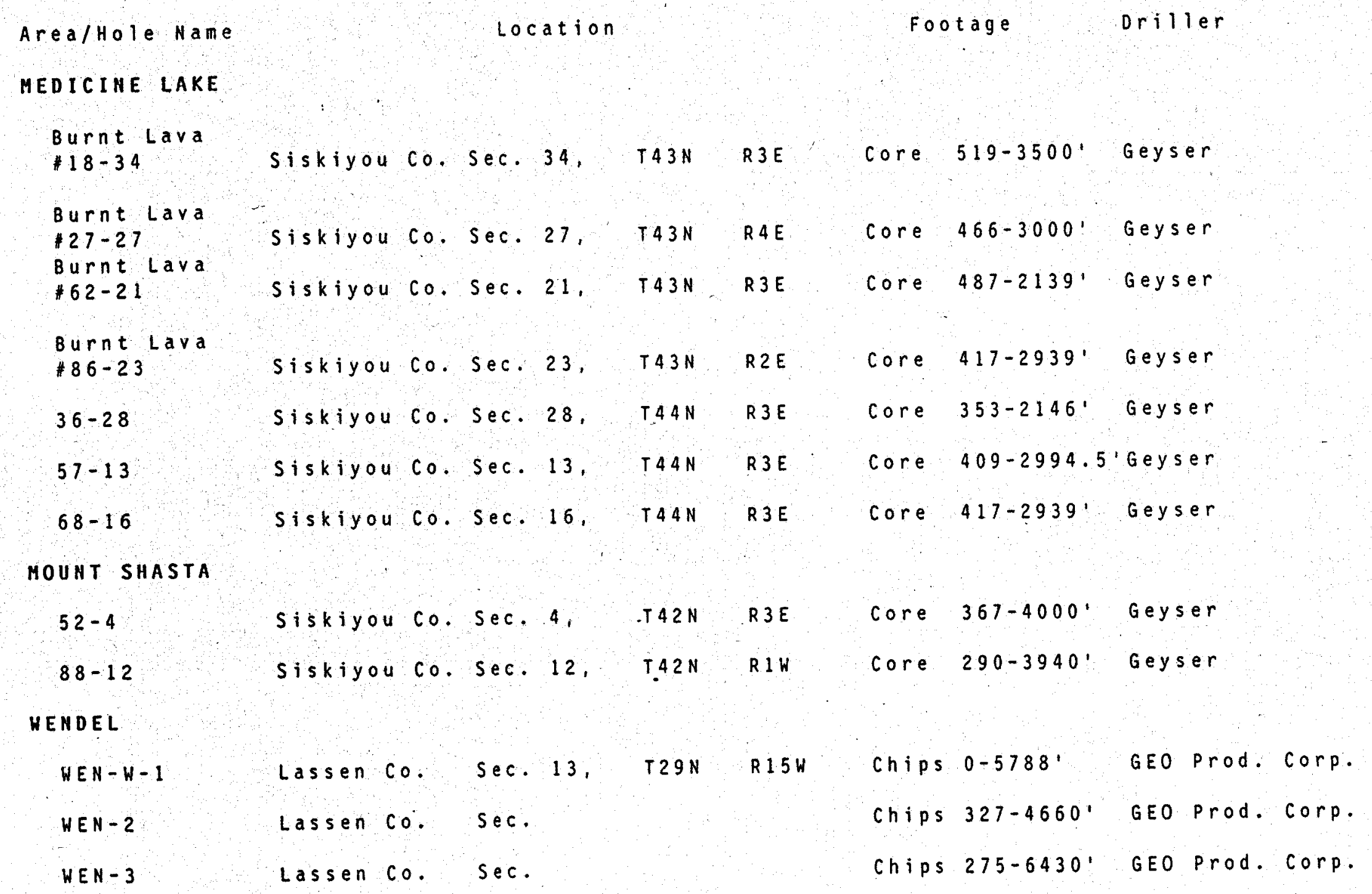


PAGOSA SPRINGS

$$
\begin{aligned}
& P S-3 \\
& P S-4 \\
& P S-5
\end{aligned}
$$

\section{Area/Hole Name}

MCG \# 1

INEL

INEL

\section{RAFT RIVER}

RRGE $\approx 2$

$R R G E: 3$

R.RGE 3 C

RRGP\#4(Leg B)

R R G P \# 5

RRG I 6

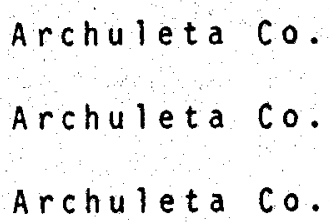

I DAHO

\section{Location}

Madison Co. Sec. $31, T 6 \mathrm{~N}$

Butteco. Sec. 1, T3N

R $40 E$

R29E

Butteco. Sec. 1, T3N

R29E

Cassia Co. Sec. 23, T $15 \mathrm{~S}$

Cassia co. Sec. 23, T15s

R2 $6 \mathrm{E}$

R2 $6 E$

Cassia Co. Sec. $25, T 15 \mathrm{~S}$

R2 $6 \mathrm{E}$

Cassia Co. Sec. $25, T 15 \mathrm{~S}$

R26E

Cassia Co. Sec. 25, T15S

R2 6E

Cassia Co..Sec. 22, TI5S

R26E

Cassia Co. Sec. 25, T15S
Footage

oriller

Chips $0-240^{\prime}$

Chips $0-300^{\circ}$

Chips $0-200^{\circ}$

Chaffee Geothermal

Chaffee Geothermal

Footage

Driller

Chips $200-3140^{\prime}$

Energy service Inc.

Chips $0-10-324^{\prime}$ DOE

Core Variable DOE

$\begin{array}{ll}\text { Core Variable } & \text { DOE } \\ \text { core variable } & \text { DOE } \\ \text { core Variable DOE } \\ \text { Core Variable DOE } \\ \text { Core Variable DOE } \\ \text { Core Variable DOE } \\ \text { Core Variable } D O E\end{array}$


IDAHO cont.

Area/Hole Name RAFT RIVER RRGI\# 7 Area/hole Name B ACA 9RD $5 \mathrm{~A}$ $9 R D 5$ $17 R D 1$ 19 20 $20 R D 1$ 21 22 22RD 1 $22 R D 2$ $22 R D \quad 3$

\section{Location}

Cassia co. Sec. $25, T 16 \mathrm{~S}$

R26E

NEW MEXICO

Location

Footage Driller
$2100-5500^{\circ}$
$2100-2800^{\prime}$
$3240-6254^{\prime}$
$60-5600^{\circ}$
$87-6860^{\circ}$
$2580-6374$
$40-2842$ !
$90-5980^{\circ}$
$2840-6485^{\circ}$
$2760-6000^{\circ}$
$2660-8800^{\circ}$
$40-5780^{\circ}$ 


\section{BALTAZOR}

\begin{tabular}{|c|c|c|c|c|c|c|c|c|c|c|c|c|}
\hline $1500-1$ & Humboldt & Co. & sec. & 13 & $T 46 N$ & $R 28 E$ & Chips & $0-1581^{\prime}$ & Earth & Power & Pro. & Co. \\
\hline $1500-7$ & $\mathrm{Humboldt}$ & Co. & Sec. & 14 & $\mathrm{~T} 46 \mathrm{~N}$ & R2 $8 E$ & Chips & $0-1487^{\circ}$ & Earth & Power & Pro. & $\mathrm{Co}$. \\
\hline 2 & Humboldt & Co. & sec. & 3 & $T 46 \mathrm{~N}$ & R $28 E$ & Chips & $0-170^{\circ}$ & Earth & Power & $\begin{array}{c}\text { Pro. } \\
-\end{array}$ & Co. \\
\hline Howard 189 & Humboldt & $\mathrm{Co}$. & sec. & 24 & T 4 4N & $R 31 E$ & Chips & $0-200^{\prime}$ & Earth & Power & Pro. & co. \\
\hline 117 & Humboldt & co. & Sec. & 16. & $T 46 \mathrm{~N}$ & R2 $8 E$ & $\mathrm{Chips}$ & $0-220^{\prime}$ & Earth & Power & Pro. & $\mathrm{CO}$. \\
\hline 122 & Humboldt & Co. & $\mathrm{Sec}$. & 25 & $T 46 \mathrm{~N}$ & R28E & Chips & $0-280^{\circ}$ & Earth & Power & Pro. & 0 \\
\hline $143-A$ & $H u m b 0.1 d t$ & Co. & Sec. & 10 & T $45 \mathrm{~N}$ & $R 27 E$ & Chips & $0-200^{\circ}$ & Earth & Power & Pro. & 0. \\
\hline 189 & $H u m b \circ I d t$ & Co. & Sec. & 24, & T $44 \mathrm{~N}$ & R31E & Chips & $0-200$ & Earth & Power & Pro. & - \\
\hline 213 & $H u m b \circ / d t$ & Co. & sec. & 1 & T $46 \mathrm{~N}$ & $R 28 E$ & Chips & $0-260^{\circ}$ & Earth & Power & Pro. & Co. \\
\hline 215 & $H u m b \circ I d t$ & $\mathrm{Co}$ & sec.: & 14 & T $46 \mathrm{~N}$ & R28E & Chips & $0-100^{\prime}$ & Earth & Power & Pro. & $\cdot$ \\
\hline $101-5$ & Humboldt & Co. & Sec. & 7. & T47N & $R 30 E$ & Chips & $0-100^{\circ}$ & Earth & Power & Pro. & Co. \\
\hline $101-6$ & $H u m b \circ 1 d t$ & Co. & Sec. & 36. & T42N & $R 29 E$ & Chips & $0-280^{\prime}$ & Earth & Power & Pro. & . \\
\hline $101-7$ & $\mathrm{Humboldt}$ & Co. & sec. & 34 & T. $46 \mathrm{~N}$ & R2 $8 E$ & Chips & $0-300^{\prime}$ & Earth & Power & Pro. & \\
\hline $101-12$ & $H u m b \circ 1 d t$ & co. & sec. & 5 & $T 47 \mathrm{~N}$ & R $30 E$ & Chips & $0-270 !$ & Earth & Power & Pro. & Co. \\
\hline $101-99$ & Humboldt & Co. & sec. & 16 & T47N & R3OE & Chips & $0-300^{\circ}$ & Earth & Power & Pro. & $\mathrm{CO}$. \\
\hline $45-14$ & $H u m b \circ I d t$ & Co. & & & & & Chips & $20-2345^{\prime}$ & Earth & Power & Pro. & . \\
\hline$B-2-79$ & Eureka Co & o. $\mathrm{Se}$ & ec. 5 , & & T31N & $R 48 E$ & Chips & $0-500^{\prime}$ & Chevro & & & \\
\hline
\end{tabular}




\section{NEVADA cont.}

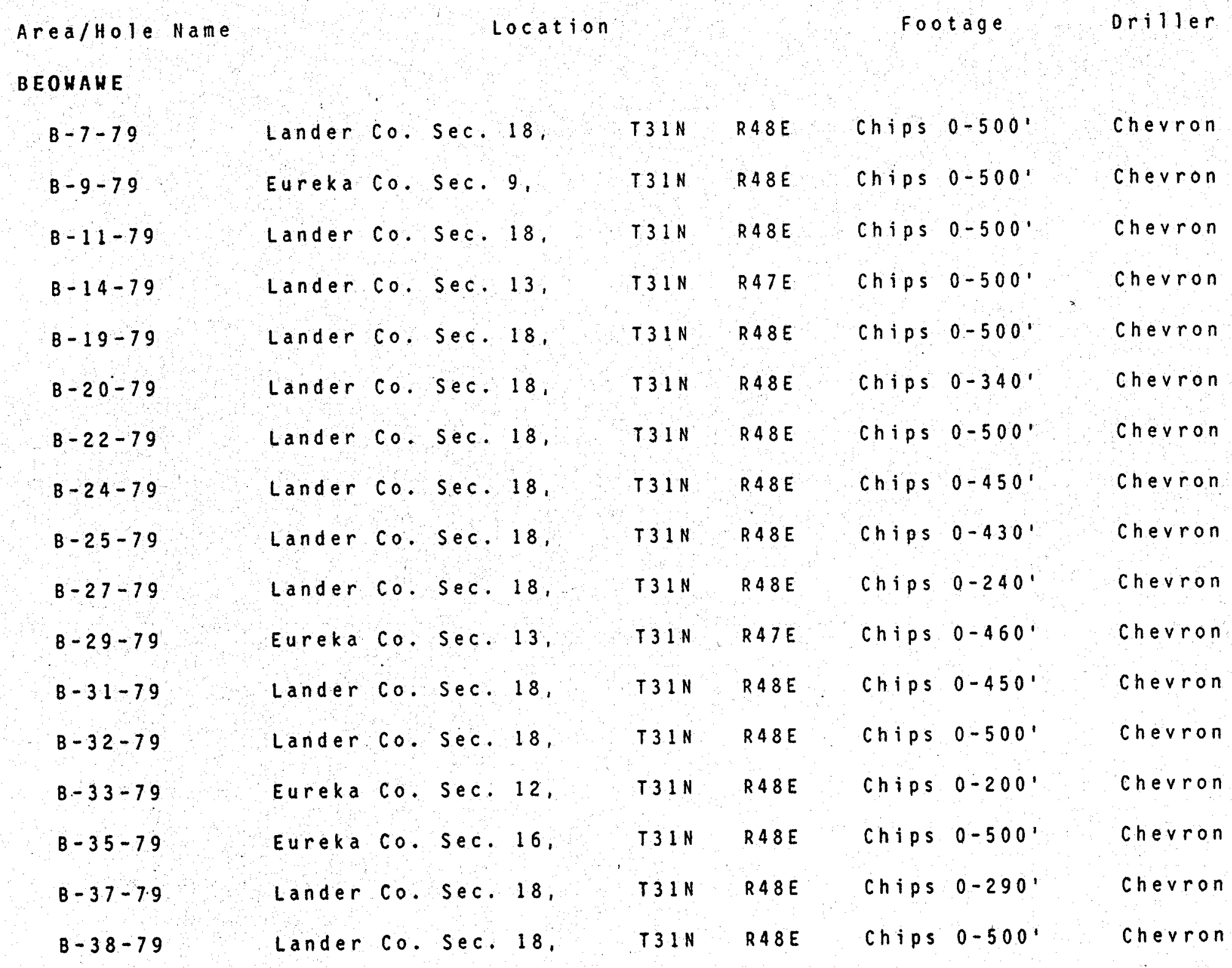


NEVADA cont.

\section{Area/Hole Name}

\section{BEOHAHE}

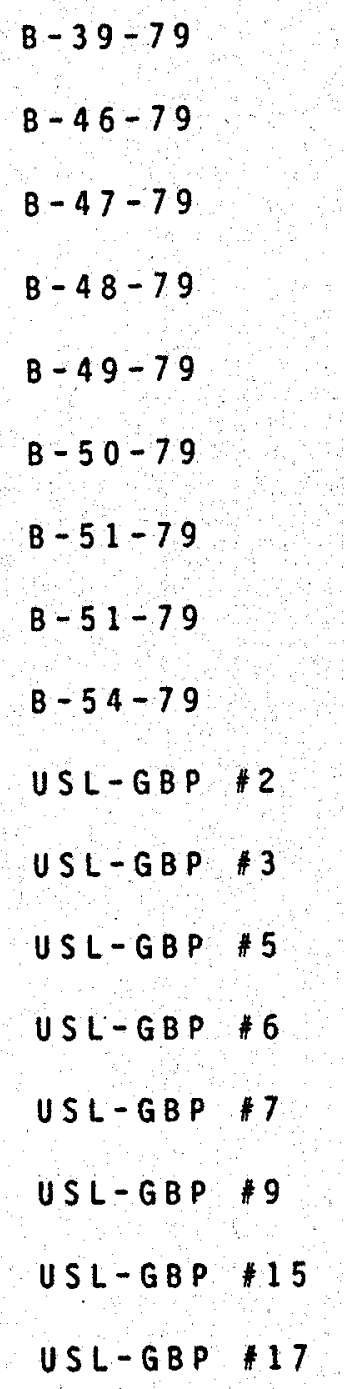

\begin{tabular}{|c|c|c|c|c|c|c|c|c|}
\hline Eureka & Co. & Sec. & 17. & T3IN & R48E & Chips & $0-420^{\prime}$ & Chevron \\
\hline Eureka & Co. & Sec. & 13 & T31N & R $48 E$ & Chips & $0-160^{\circ}$ & Chevron \\
\hline Eureka & Co. & Sec. & 20. & $T 31 \mathrm{~N}$ & $R 48 E$ & Chips & $0-390^{\circ}$ & Chevron \\
\hline Eureka & Co. & Sec. & 21, & $T 31 \mathrm{~N}$ & $R 48 E$ & Chips & $0-490^{\circ}$ & Chevron \\
\hline Eureka & $\mathrm{Co}$. & Sec. & 24, & T $31 N$ & R $48 \mathrm{E}$ & Chips & $0-500^{\circ}$ & Chevron \\
\hline Lander & $\mathrm{Co}$ & sec. & 18 & T31N & R 48E & Chips & $0-330^{\circ}$ & Chevron \\
\hline Lander & $\mathrm{Co}$ & sec. & 19, & T $31 \mathrm{~N}$ & R48E & Chips & $0-430^{\circ}$ & Chevron \\
\hline Lander & Co. & Sec. & 19, & $T 31 \mathrm{~N}$ & R48E & Chips & $0-140^{\prime}$ & Chevron \\
\hline Eureka & $\mathrm{CO}$. & Sec. & 24 & $T 31 \mathrm{~N}$ & R 48E & Chips & $0-45-0^{\prime}$ & Cherron \\
\hline Lander & Co. & Sec. & 17 & T $31 \mathrm{~N}$ & R48E & Chips & $0-500^{\prime}$ & Get ty \\
\hline Lander & Co. & Sec. & & T31N & R48E & Chips & $0-500 !$ & Getty \\
\hline Lander & $\mathrm{CO}$ & Sec. & 16 & T3IN & $R 48 E$ & Chips & $0-500^{\circ}$ & Getty $0 i 1$ \\
\hline Lander. & $\mathrm{Co}$. & Sec. & 20 & $T 31 \mathrm{~N}$ & $R 48 E$ & Chips & $0-500^{\prime}$ & Getty $0 i l$ \\
\hline Lander & Co. & sec. & 22 & $T 31 \mathrm{~N}$ & R48E & Chips & $0-500^{\prime}$ & Getty $0 i 1$ \\
\hline Lander & Co. & Sec, & 22, & T31N & R 48E & Chips & $0-480^{\prime}$ & Getty $0 i l$ \\
\hline Lander & Co. & Sec. & 20, & $T 31 \mathrm{~N}$ & R48E & Chips & $0-500^{\prime}$ & Getty 0 il \\
\hline Lander & Co. & Sec. & 16, & T31N & R48E & Chips & $0-500^{\circ}$ & Getty $0 i_{1}$ \\
\hline
\end{tabular}

Location footage oriller 


\section{BEOUAHE}

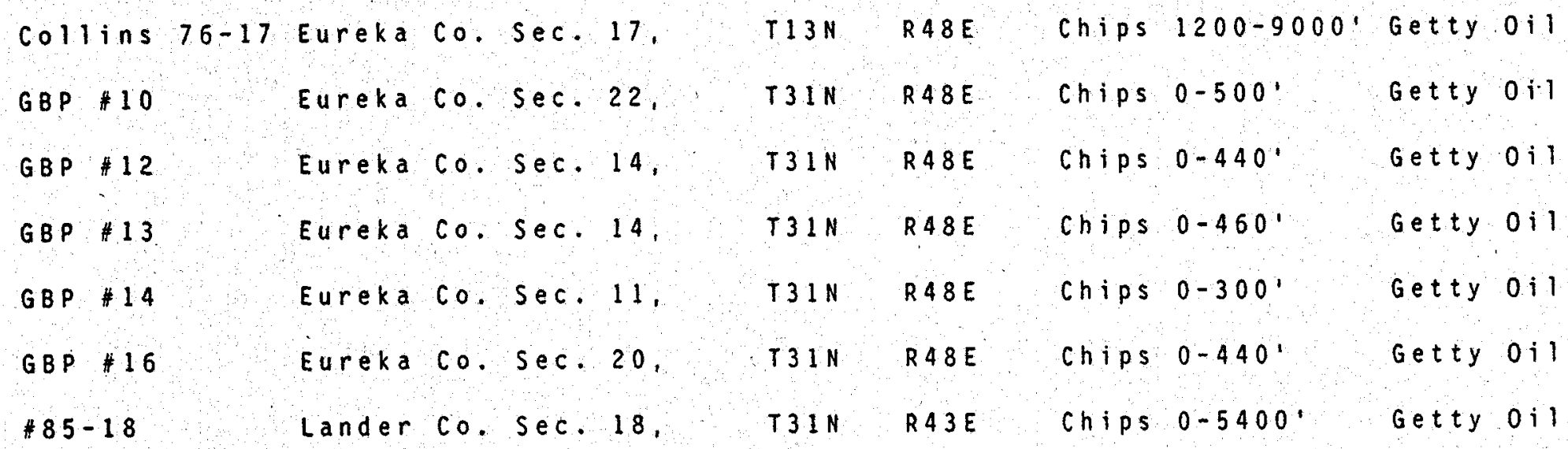

\section{COLADO}

\begin{tabular}{|c|c|c|c|c|c|c|c|c|c|c|}
\hline $8-34$ & Pershing & Co. & Sec. & 34 & $T 28 \mathrm{~N}$ & R $32 E$ & Chips & $0-500^{\prime}$ & Getty & $0 i 1$ \\
\hline $1-12$ & Pershing & Co. & Sec. & 12. & $T 27 \mathrm{~N}$ & R $32 E$ & Chips & $0-500^{\circ}$ & Getty & $0 i 1$ \\
\hline $9-34$ & Pershing & Co. & sec. & 34 & T28N & R $32 \mathrm{E}$ & Chips & $0-500^{\circ}$ & Get $t y$ & $0 i 1$ \\
\hline $3-10$ & Pershing & Co. & sec. & 10 & T27N & R $32 E$ & Chips & $0-500 \ldots$ & Getty & 011 \\
\hline $4-16$ & Pershing & Co. & sec. & 16. & T27N & R $32 \mathrm{E}$ & Chips & $0-500^{4}$ & Get ty & $0 i 1$ \\
\hline $12-26$ & Pershing & Co.. & Sec. & 26 & $T 28 N$ & R32E & Chips & $0-300^{\prime}$ & Get ty & 0 il \\
\hline $2-2$ & Pershing & $\mathrm{CO}$ & Sec. & 2, & $T 27 \mathrm{~N}$ & R $32 \mathrm{E}$ & Chips & $0-500^{\prime}$ & Getty & $0 i 1$ \\
\hline $15-21$ & Pershing & Co. & Sec. & 21. & T28N & R $32 E$ & Chips & $0-500^{\circ}$ & Getty & $0+1$ \\
\hline $10-34$ & Pershing & Co. & Sec. & 34. & $T 28 \mathrm{~N}$ & R32E & Chips & $0-5001$ & Getty & $0 i 1$ \\
\hline
\end{tabular}




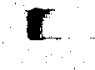

\section{Area/Hole Name}

COLADO

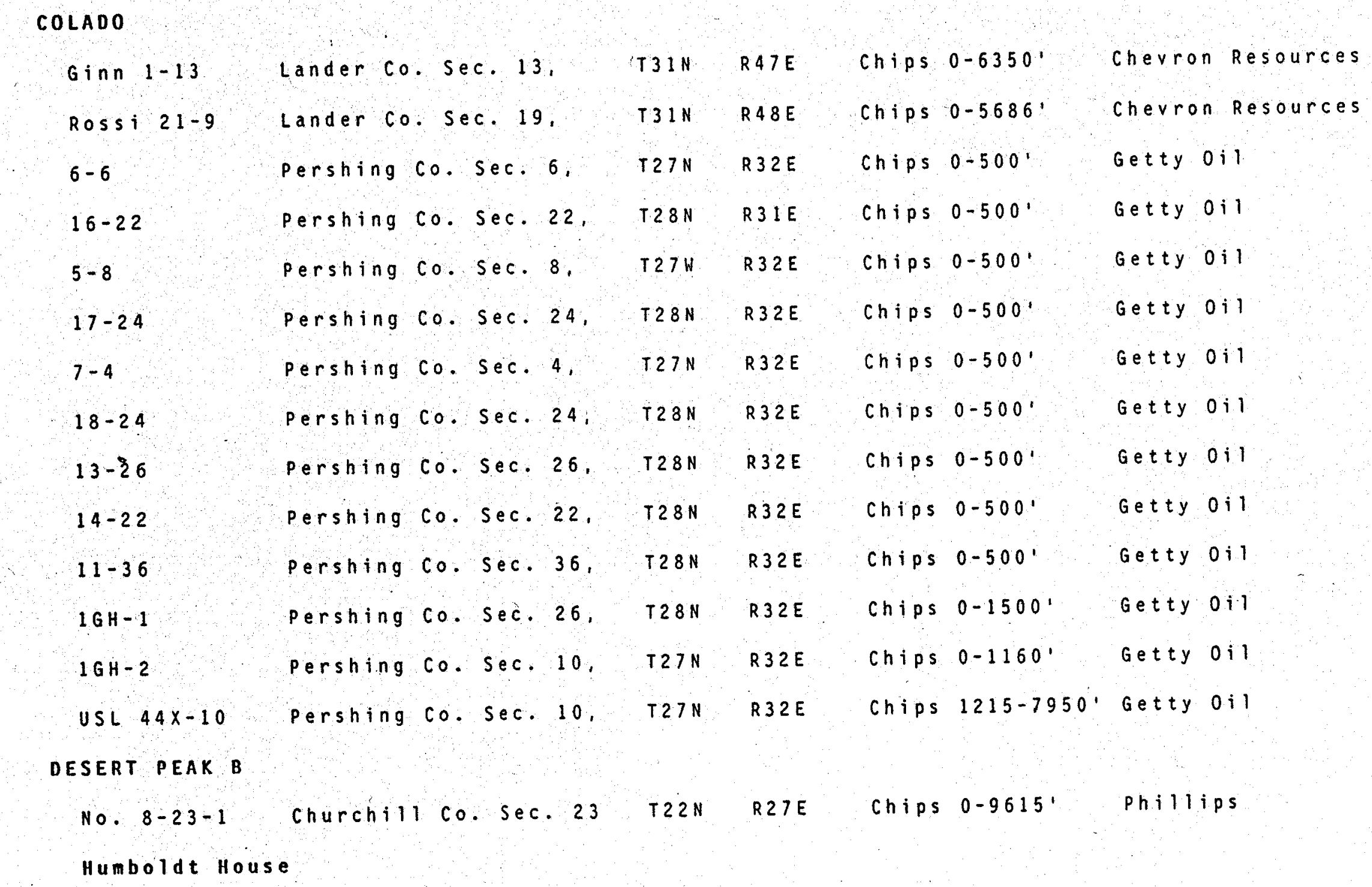

\section{NEVADA cont.}

\section{Location}

Footage

oriller 


\section{DESERT PEAK B}

Campbell "E" 2 pershing Co. Sec. 15, T31N R33E Chips $0-8061$ Phillips DIXIE FEDERAL

45-14 Churchill Co. Sec. 14, T23N R35E Chips $0-9020$ O Thermal Power
66-21 Churchill Co. Sec. 21, T22N R36E Chips $0-9780^{\circ}$ Thermal Power

\section{DIXIE VALLEY}

$\begin{array}{lc}\text { SR-4 } & \text { Chur } \\ S R-3 & \text { Chur } \\ \text { ISH LAKE } & \\ 88-11 A & \text { Nye } \\ 88-11 & \text { Nye }\end{array}$

\section{LEACH HOT SPRING}

\section{SUNEDCO 11-36 Pershing Co.}

Chips $0-8565^{\circ}$ AMINOIL

\section{MCCOY}

$\begin{array}{ll}66-8 & \text { Churchill Co. } \\ 14-7 & \text { Churchill Co. } \\ 26-8 & \text { Churchill Co. } \\ 26-8 & \text { Churchill Co. }\end{array}$

Chips $0-8580^{\circ}$

Chips $0-8120^{\circ}$

AMAX

Chips $0-2500^{\circ}$ AMAX

Chips $0-940^{\circ} \quad$ AMAX

Chips $0-2094^{\circ}$ AMAX

Core 1001-2094 AMAX 





\section{NEWBERRY}

$$
\begin{aligned}
& N-1 \\
& N-3
\end{aligned}
$$

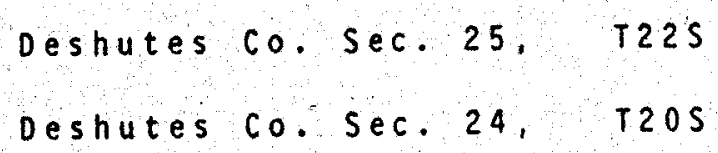

R $12 E$

Core 453-4002:

Geo Newberry

OLD MAID FLAT

Fenix \&

scission $7 \mathrm{~A}$

clackamas co. Sec. 15, T2S

R $8 E$

Chips $0-6018$ :

Fenix \& scission

ORE-IDA

1

Malheur Co. Sec. 3

T18S

R $47 \mathrm{E}$

Chips $0-10,054^{\prime}$

ore-Ida foods

1

Malheur Co. Sec. 3

R $47 E$

Core Variable

ore-Ida foods

TEXAS

Area/Hole Name

Location

LACKLAND A.F.B.

$\begin{array}{ll}\text { Lackland } & \text { Bexer Co. } \\ \text { lackland } \quad \text { Bexer Co. }\end{array}$

Chips $0-4130^{\circ}$

Chips $0-4128^{\prime}$

UTAH

Area/Hole Name

Location

Footage

Driller

\section{COVE FORT}

B 1 ack Rock

$5-79 / 2204$

Beaver co.

SeC.18 ADA T24S RIIW

Core $19.0-204.7$

Sec. 6

T.30S

R 9 W

Hunt Energy 
UTAH cont.

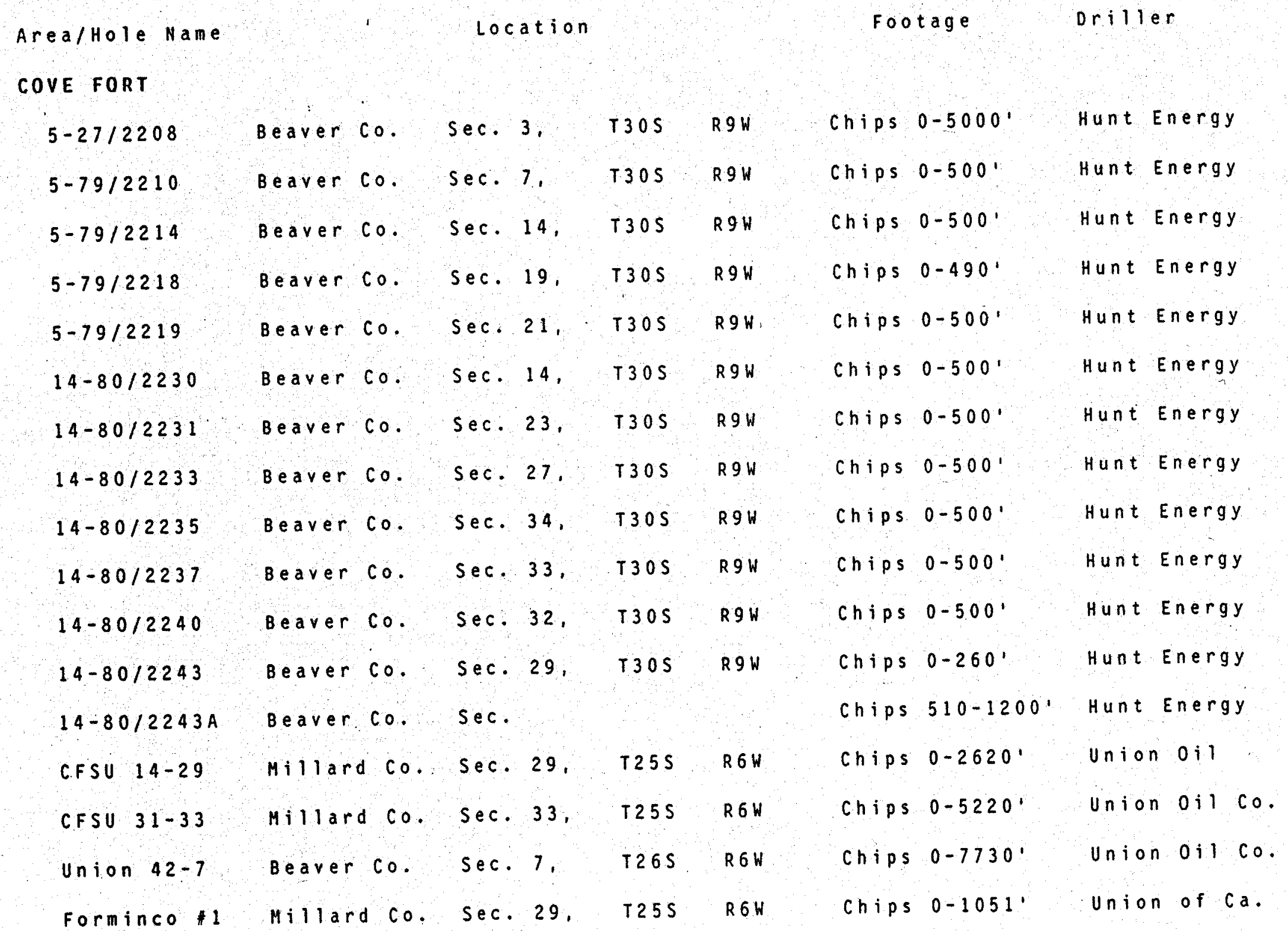


UTAH cont.

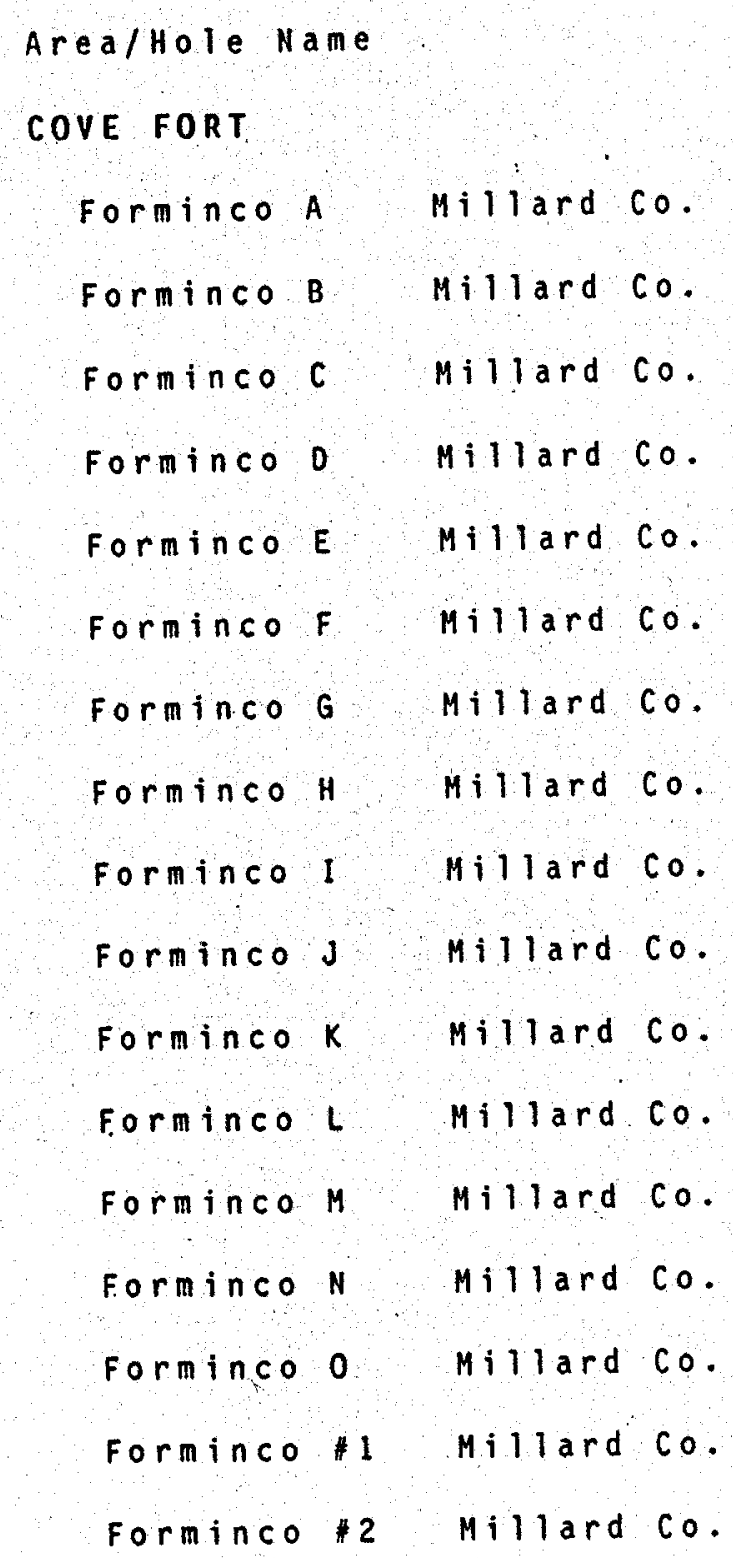

Footage

Driller

\begin{tabular}{|c|c|c|c|}
\hline Chips & $0-300$ & Union & $0 i 1$ \\
\hline Chips & $0-110^{\prime}$ & Union & $0 i 1$ \\
\hline Chips & $0-300^{\circ}$ & Union & $0 \mathrm{il}$ \\
\hline Chips & $0-90 !$ & Union & $0 i 1$ \\
\hline Chips & $0-300^{\circ}$ & Union. & $0 i 1$ \\
\hline Chips & $150-255^{\prime}$ & Union & $0 i 1$ \\
\hline Chips & $0-300^{\prime}$ & Union & $0 i 1$ \\
\hline Chips & $0-300^{\prime}$ & Union & $0 i 1$ \\
\hline Chips & $0-245$ & Union & $0 i 1$ \\
\hline Chips & $0-300^{\prime}$ & Union & $0 i 1$ \\
\hline Chips & $0-250^{\circ}$ & Union & 0 i 1 \\
\hline Chips & $0-250^{\circ}$ & Union & $0 ; 1$ \\
\hline Chips & $0-250^{\circ}$ & Union & $0 i 1$ \\
\hline Chips & $0-120^{\circ}$ & Union & $0 i 1$ \\
\hline Chips & $0-250^{\prime}$ & Union & 0 il \\
\hline Chips & $0-250^{\circ}$ & Union & $0 \mathrm{il}$ \\
\hline Chips & $0-250^{\circ}$ & Union & $0 i 1$ \\
\hline
\end{tabular}


Driller

\section{HILL AIR FORCE BASE}

2

Davis Co.

\section{ROOSEVELT}

\begin{tabular}{|c|c|c|c|c|c|c|c|c|c|c|}
\hline Getty $52-21$ & Beaver & $\mathrm{Co}$ & sec. & 21. & $\mathrm{~T} 27 \mathrm{~S}$ & $R 9 W$ & Chips & $0-7500^{\prime}$ & Getty Oil Co. & \\
\hline Getty $52-21$ & Beaver & Co. & sec. & 21 & $T 27 \mathrm{~S}$ & $R 9 W$ & Core & $\operatorname{variable}$ & Getty $0 i 1 \mathrm{Co}$. & \\
\hline TPC $72-16$ & Beaver & Co. & sec. & 16. & $T 27 \mathrm{~S}$ & R9W & Chips & $0-1244^{\prime}$ & Thermal Power & Co. \\
\hline$G P C-1$ & Beaver & Co. & sec. & 1, & T27S & R $10 \mathrm{~W}$ & Chips & $0-400^{\prime}$ & Geoth. & Corp. \\
\hline$G P C-2$ & Beaver & Co. & sec. & 6 , & $\mathrm{T} 27 \mathrm{~S}$ & R 9 W & Chips & $0-300^{\circ}$ & Geoth. & Corp. \\
\hline GPC $-\mathbf{3}$ & Beaver & Co. & Sec. & 4, & $\mathrm{~T} 27 \mathrm{~S}$ & $\mathrm{R} 9 \mathrm{~W}$. & Chips & $0-300$ & Geoth. Power & Corp. \\
\hline$G P C-4$ & Beaver & Co. & sec. & 33 & T27S & R9W & Chips & $0-300^{\circ}$ & Geoth. & Corp. \\
\hline$G P C-5$ & Be a ver & Co. & Sec. & 34 & $127 \mathrm{~S}$ & R9 W & Chips & $0-180^{\prime}$ & Geoth. & corp. \\
\hline$G P C-6$ & Beaver & Co. & Sec. & 25 & T27 S & $R 10 W$ & Chips & $0-300^{\circ}$ & Geoth. Power & Corp. \\
\hline$G P C-7$ & Beaver & $\mathrm{Co}$. & Sec. & 13 & $T 27 \mathrm{~S}$ & R $9 W$ & Chips & $0-30.0^{1}$ & Geoth. Power & corp. \\
\hline$G P C-8$ & Beaver & Co. & Sec. & 25 & $T 26 \mathrm{~S}$ & R 9 W & Chips & $0-360^{\circ}$ & Geoth. Power & Corp. \\
\hline$G \cdot P C-9$ & Beaver & Co. & Sec. & 12, & $\mathrm{~T} 26 \mathrm{~S}$ & $\mathrm{R} 8 \mathrm{~W}$ & Chips & $0-290^{\circ}$ & Power & corp. \\
\hline GPC- 10 & Beaver & Co. & Sec. & 6. & $\mathrm{~T} 26 \mathrm{~S}$ & R $8 \mathrm{~W}$ & Chips & $0-196^{\circ}$ & Geoth. Power & Corp. \\
\hline$G P C-11$ & Beaver & Co. & Sec. & 17. & T26S & R $8 \mathrm{~W}$ & Chips & $0-110^{\circ}$ & Geoth. Power & Corp \\
\hline$G P C-12$ & Beaver & Co. & Sec. & & T26S & R7W & Chips & $0-260^{\circ}$ & Geoth. Power & corp. \\
\hline
\end{tabular}

Chips $0-3260^{\circ}$ Univ. of Utah 


\section{ROOSEVELT}

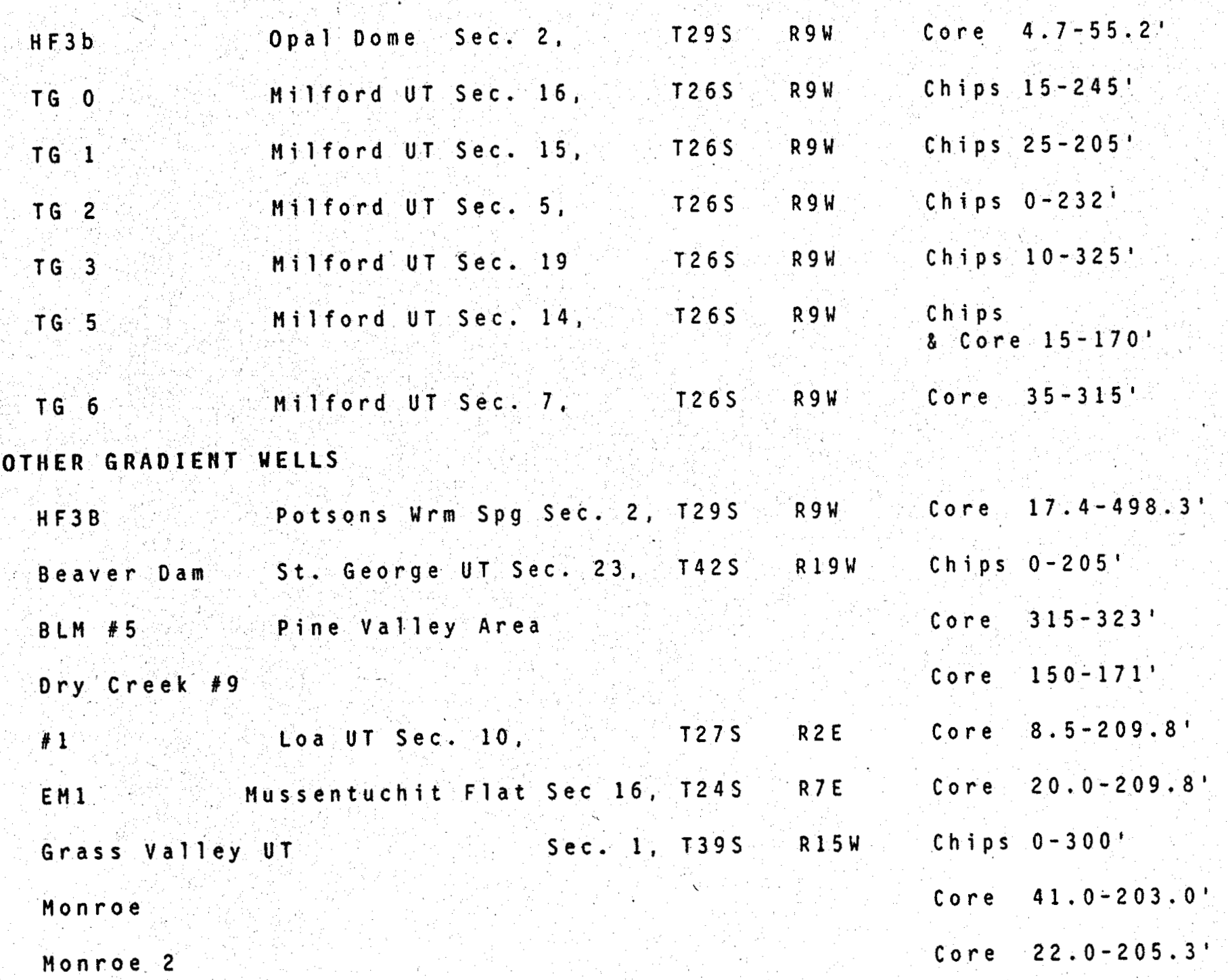


arrrrr $r$

Area/Hole Name

Location

UINTAH BASIN

Petrodynel Jensen \# 3

UTAH ROSES

2

Savage Well

Salt Lake Co.

Salt Lake Sec. 22 ,

T2

WASHINGTON

oriller

\section{GLACIER PEAK}

103 holes with a total of 51,698 feet of core

WYOMING

\section{Area/Hole Name}

Research

Tech. Corp.
Niobrara so. Sec. 11 ,
Footage

Chips 1475-7850. Res. Tech. Corp. 
UTAH cont.

Area/Hole Name

Location

\section{OTHER GRADIENT UELLS}

\section{Monroe 3 \\ Monroe $M 4$ \\ Monroe 6}

Panguitch Lake UT

Shautie Hill UT

Thermo la

\section{HARM SPRINGS FAULT}

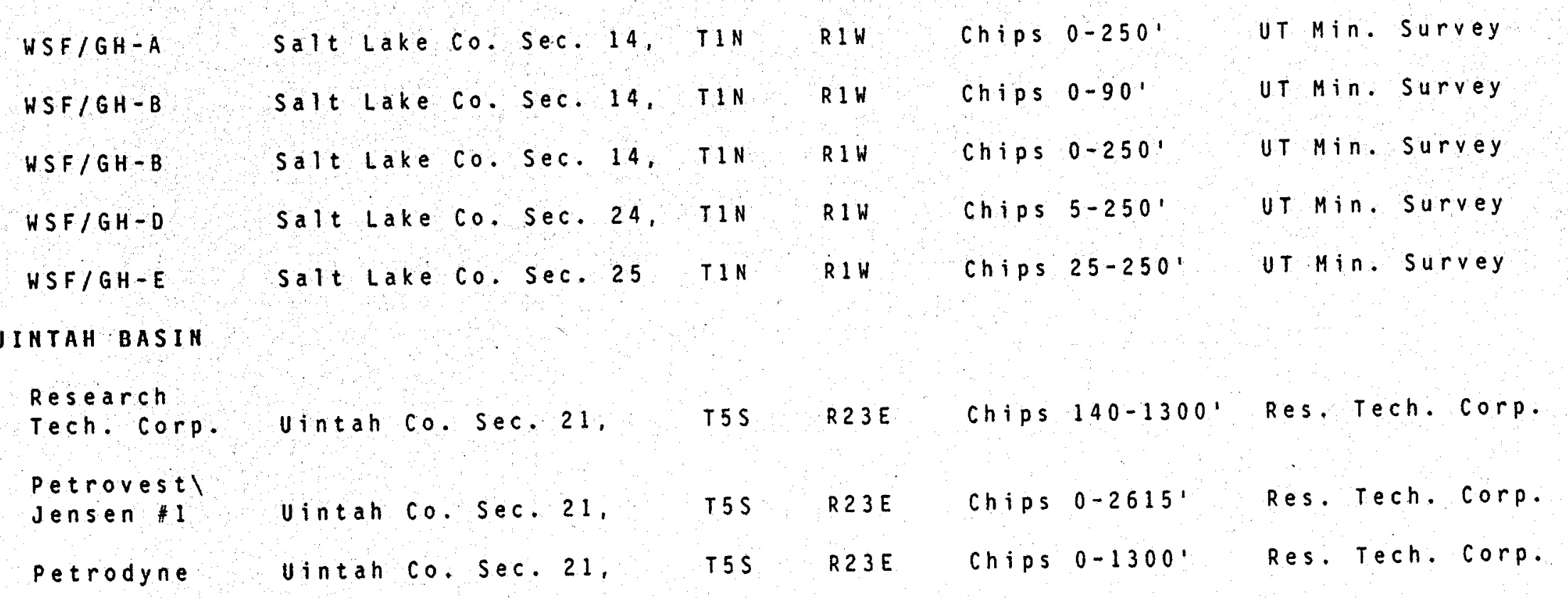

\section{Footage \\ Driller}

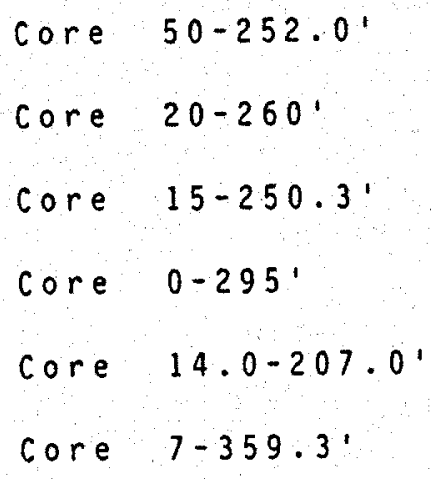




\section{MEAGER CREEK}

$M C G-1$
$M C G-2$
$M C G-3$
$M-1$
$M-2$
$M-3$
$M-7$
$M-7$
$M-8$
$M-8$
$M-9$
$M-9$
$M 10-80 D$
$M 10-80 D$
$M 13-81-D$
$M 13-81-0$

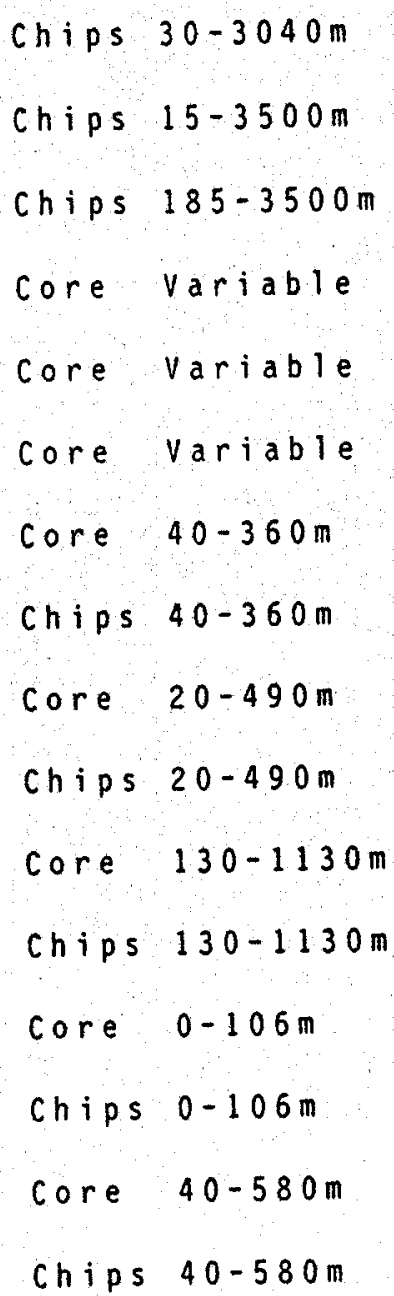




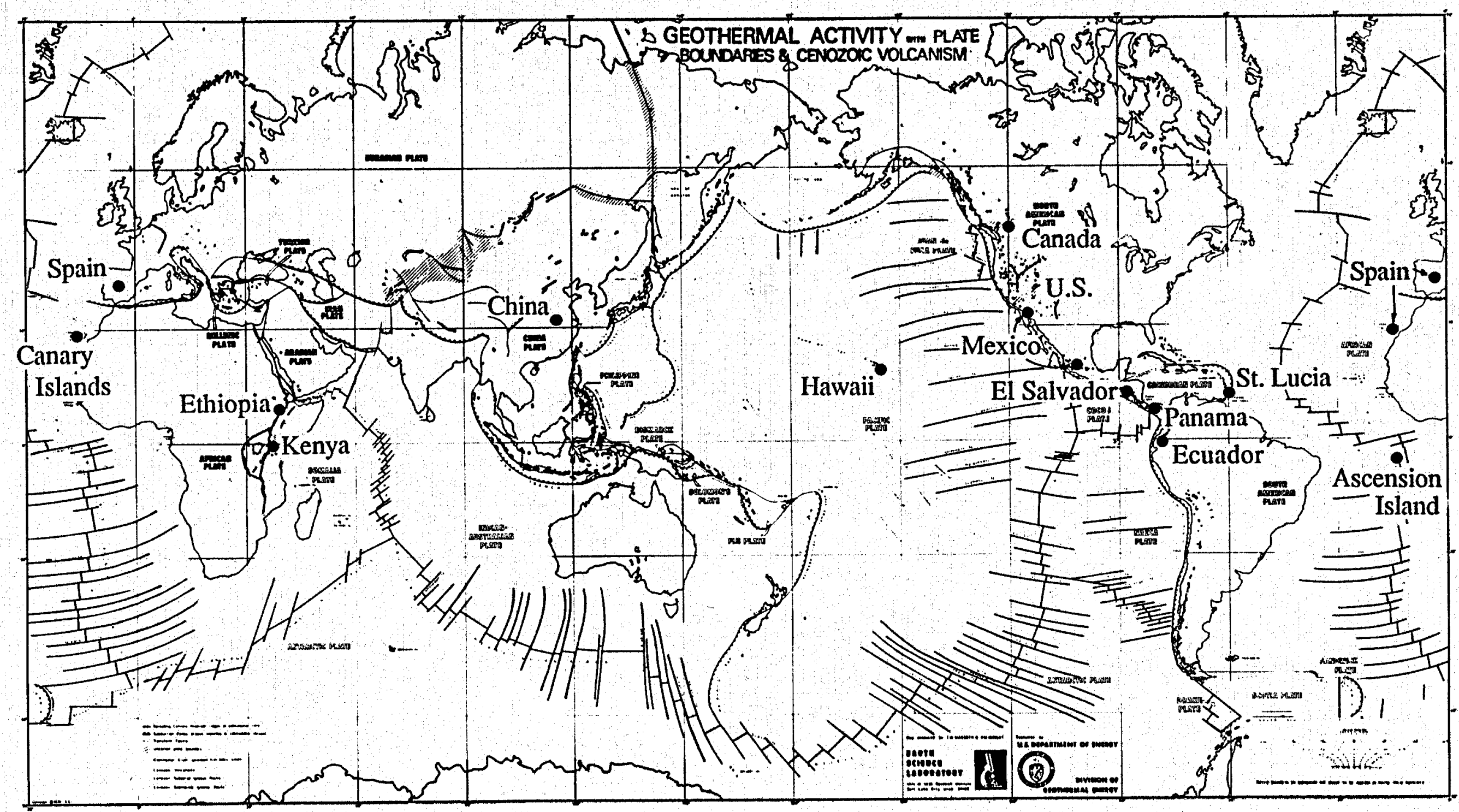

Figure 4. UURI Geothermal Studies - Worldwide 

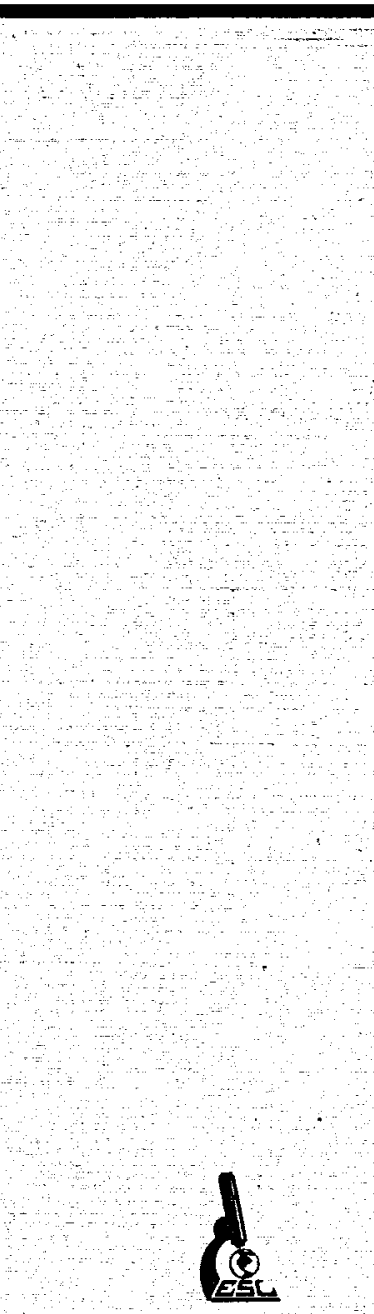

EARTH SCIENCE LABORATORY 391 CHIPETA WAY, SUITE C

SALT LAKE CITY, UTAH 84108 (801) 5243422 